The following document is a pre-print version of:

Galloway S, Ross P-S, Bandyayera D, Daoudene Y (2019) Contemporaneously erupted tholeiitic and calc-alkaline magmas in the Archean Colomb-Chaboullié greenstone belt, James Bay, Quebec: petrologic implications. Precambrian Research 331:article 105363

\title{
Contemporaneously erupted tholeiitic and calc-alkaline magmas in the Archean Colomb-Chaboullié greenstone belt, James Bay, Quebec: petrologic implications
}

\author{
S. Galloway ${ }^{\mathrm{a}}$ P.-S. Ross ${ }^{\mathrm{a} *}$, D. Bandyayera ${ }^{\mathrm{b}}$, Y. Daoudene ${ }^{\mathrm{b}}$ \\ ${ }^{a}$ Institut national de la recherche scientifique, Centre Eau Terre Environnement, 490 rue de la Couronne, Québec (QC), G1K \\ 9A9, Canada \\ ${ }^{\text {b }}$ Ministère de l'Énergie et des Ressources naturelles (Québec), 5700 4 Av. O, Québec (QC), G1H 6R1, Canada \\ *Corresponding author: rossps@ete.inrs.ca
}

\begin{abstract}
Archean greenstone terranes are key to understanding the geological processes active during early Earth history. These areas are also of economic interest due to their association with volcanogenic massive sulphide (VMS) deposits, and several other types of mineral deposits. The Archean Colomb-Chaboullié greenstone belt is located between the Nemiscau and Opatica subprovinces of the Superior Province, Quebec, Canada. This belt comprises three submarine volcanic units: pillowed to massive basaltic lavas, variably porphyritic massive to pillowed intermediate lavas ( \pm intrusions), and intermediate to felsic volcaniclastic rocks. The calc-alkaline intermediate lavas and volcaniclastic assemblages are intercalated with the tholeiitic to transitional basaltic lavas. This implies that these volcanic rocks were contemporaneously formed within a limited geographical area. The major element trends of the basalts are explained by crystal fractionation while the trace elements are influenced by independently occurring minor degrees of crustal contamination. The major and trace element geochemistry of the calc-alkaline rocks share many geochemical characteristics with pre-existing crustal contaminants. We therefore propose that the intermediate and felsic assemblages were produced via crustal contamination and mixing processes within a pre-existing magma chamber. The basalts spent less time in the crust and had a more direct passage to the surface.

Massive to semi-massive $\mathrm{Au}-\mathrm{Ag}-\mathrm{Cu}$ showings along with associated paleo-hydrothermal manifestations are dominantly associated with the basaltic lavas, and show evidence of a syn-volcanic origin. Chemo-stratigraphy, in conjunction with detailed mapping of the gold-bearing Lac Marcaut VMS showing, allows a basalt-basalt contact to be identified, which may be favourable for exploration elsewhere in the Colomb-Chaboullié belt.
\end{abstract}

\section{Introduction}

Greenstone belts, which are areas of mostly mafic volcanic rocks surrounded by large granitoid terrains (Condie, 1981), are geologically important regions. They are key to understanding the geodynamic processes during the Archean, and even early life (e.g., Polat and Kerrich, 2001; Kerrich and Polat, 2006; Westall et al., 2006; O'Neil et al., 2011, 2012, 2013; Bédard et al., 2013; Bédard and Harris, 2014; Moyen and Laurent 2018; Smithies et al., 2018). They also host numerous mineral deposit types including volcanogenic massive sulphide (VMS) deposits (Franklin et al., 2005; Galley et al., 2007), Ni-Cu \pm platinum-group element (PGE) sulphide deposits (Arndt et al., 2005; Maier and Groves, 2011), and orogenic gold deposits (Groves et al., 1998; Poulsen et al., 2000; Goldfarb et al., 2005).
Large greenstone belts such as the Abitibi greenstone belt of the Superior Province in Canada and the Barberton belt in South Africa have provided ample data on their metamorphism, stratigraphy, geochemistry, and mineralisation (e.g., Laflèche et al., 1992; Powell et al., 1995; Thurston et al., 2008; Altigani et al., 2016).

However, the study of smaller greenstone belts, such as the Colomb-Chaboullié of the Superior Province in Canada, is useful as these are stratigraphically, and hopefully petrologically, less complex than larger greenstone belts. Another reason to map and study smaller greenstone belts is that they are economically underexplored; better knowledge of the volcanic stratigraphy for example, is a bonus for VMS exploration. 
In this contribution, we present a geological, stratigraphic, and geochemical study of the Archean Colomb-Chaboullié greenstone belt. We speculate on the petrogenesis of the volcanic rocks based on the aforementioned information and propose that the intercalated tholeiitic basalts and calcalkaline andesites have somewhat different magmatic histories.

\section{Geological context}

The Colomb-Chaboullié greenstone belt is located at the contact between the Nemiscau and Opatica subprovinces of the Superior Province, in the James Bay area of Quebec (Fig. 1). The Superior Province is the largest Archean craton on Earth (Card, 1990; Benn and Moyen, 2008). The subdivision of the Superior Province into smaller subprovinces and domains is based on age differences and lithological, structural, metamorphic, and geophysical characteristics (Card and Ciesielski, 1986).

The Opatica Subprovince lies immediately south of the Colomb-Chaboullié greenstone belt. This is a high-grade volcano-plutonic subprovince, primarily composed of orthogneiss and granitoid rocks (Sawyer and Benn, 1993; Davis et al., 1995; Bandyayera and Daoudene, 2017), with some volcanic rocks (Boily and Dion, 2002). U-Pb ages for plutonic and gneissic rocks in the Opatica Subprovince range from 2833-2820 Ma (Davis et al., 1994) to $2678 \pm 2$ Ma (Davis et al., 1995). The Lac Rodayer pluton has an age range of 2833-2825 Ma, based on U-Pb ages (Davis et al., 1994). This is the oldest unit within the Opatica Subprovince. It is composed of four lithological subunits; Arod1, Arod2, Arod3, and Arod4 (Bandyayera and Daoudene, 2017). Arod2 and Arod3 form spatially abundant bodies of the Lac Rodayer pluton located immediately adjacent to the Colomb-Chaboullié belt. These subunits comprise variably foliated tonalites, with quartz-diorite also present in Arod3. The $2822 \mathrm{Ma}$ (J. Davis, written communication, 2018) Théodat Complex also borders the Colomb-Chaboullié belt, within the Opatica Subprovince. It is made up of six subunits; a biotite-rich gneiss (Athe 1), a massive to gneissic granodiorite unit (Athe2), a magnetic porphyritic granodiorite unit (Athe3), a gneissic granodiorite unit (Athe4), a tonalite unit (Athe5), and a pegmatite and granite unit (Athe6).

The Nemiscau Subprovince is principally a high-grade metasedimentary terrain made up largely of paragneiss, metatexites, and diatexites (Hocq, 1994), situated to the north of the Colomb-Chaboullié belt. A U-Pb zircon sample derived from a granite that cross-cuts the Nemiscau yielded a minimum age of $2672 \pm 2 \mathrm{Ma}$ (Davis et al., 1995). A depositional age of the sediments of the Nemiscau Subprovince is estimated between 2698 and $2688 \mathrm{Ma}$ (Percival et al., 1992). This is therefore not a viable source of magma contamination for the $\sim 2.76 \mathrm{Ga}$ Colomb-Chaboullié greenstone belt. The Nemiscau is subdivided into two principal regions; a plutonic terrane comprising monzonite and granodiorite rocks which contain remnants of paragneiss and amphibolites, and a metasedimentary terrain which itself is divided into three high-grade domains based on magnetic features (Hocq, 1994).

The Colomb-Chaboullié belt was most recently mapped by the Ministère de l'Énergie et des Ressources naturelles du Québec (MERN) in 2015, at a scale of 1:50 000

(Bandyayera and Daoudene, 2017). This greenstone belt measures $77 \times 5 \mathrm{~km}$ and is made up of volcanic, mafic/ultramafic intrusive, sedimentary, and metamorphic rocks (Bandyayera and Daoudene, 2017). It is dominantly composed of mafic, pillowed to massive basaltic lava flows (Fig. 2). The remaining volcanic units include variably porphyritic, pillowed to massive andesite lava flows and intermediate to felsic volcaniclastic rocks. These volcanic units have been metamorphosed to the amphibolite facies. U-Pb ages of $2756.8 \pm 4 \mathrm{Ma}$ and $2760.3 \pm 6$ Ma have been determined for zircons in these volcaniclastic rocks (David et al., in preparation). The intrusive bodies are located mostly in the west and are composed of gabbros, peridotites, and pyroxenites. There are three sedimentary units within the Colomb-Chaboullié belt. A small unit of quartzite and iron formation is located to the west, two small bands of paragneiss are present, and a thin band of polymict conglomerate is located in the eastern part of the belt (Bandyayera and Daoudene, 2017). The vast majority of the contacts between the different units had to be interpolated due to a low outcrop density, so the exact nature of most of these contacts is not known. Overall, there are not enough younging indicators to determine the detailed structure within the greenstone belt.

The MERN compiled previously recorded and newly identified mineral prospects. Six Ni-Cu-PGE prospects in the mafic/ultramafic intrusives and six VMS-style Au-Ag$\mathrm{Cu}$ prospects were confirmed or discovered in 2015. The presence of disseminated pyrite-arsenopyrite veins associated with shear zones suggests that orogenic gold mineralisation is also present in the Colomb-Chaboullié greenstone belt.

The Lac Marcaut massive sulphide showing is the best known VMS-style showing (Riopel, 1994), which extends laterally along an outcrop ridge for $80 \mathrm{~m}$ in an east-west direction, with a maximum thickness of $1.4 \mathrm{~m}$ (Thorsen et al., 1993). Borehole intersections and electromagnetic surveys show that the massive sulphide lens can be followed over a strike length of $2.8 \mathrm{~km}$ (Thorsen et al., 1993). Gold contents are anomalous throughout the sulphide unit. Borehole grades of $3.52 \mathrm{~g} / \mathrm{t}$ Au over $0.8 \mathrm{~m}$ and channel samples grades of $3.77 \mathrm{~g} / \mathrm{t} \mathrm{Au}$ across $1.85 \mathrm{~m}$ and $6.86 \mathrm{~g} / \mathrm{t} \mathrm{Au}$ across $1.3 \mathrm{~m}$ have been reported (Thorsen et al., 1993). 


\section{Methodology}

Outcrop density in the study area is low due to woody or swampy terrain. Field mapping focused on the volcanic units of the Colomb-Chaboullié greenstone belt using the 1:50 000 scale geological map of NTS sheets $32 \mathrm{~N} 03$ and $32 \mathrm{~N} 04$ as a base map. Some 69 field stations were visited, of which 39 were new and 30 had been previously mapped by the MERN in 2015. The Route de la Baie-James crosscuts the greenstone belt in a north-south direction (Fig. 2), which allowed numerous samples to be taken along this transect. More remote samples were also collected via helicopter. Over 70 samples were collected and sawed to examine in the laboratory. From this set, 45 were selected for whole rock major and trace element analyses (see Fig. 2 for locations) at Activation Laboratories in Ontario, Canada, where they were crushed to a mesh size of $105 \mu \mathrm{m}$. Major oxides, along with $\mathrm{Sr}$, were analysed via ICP-OAS. All other trace elements were determined by ICP-MS following a lithium

metaborate/tetraborate fusion process. Detection limit data, accuracy, and reproducibility are discussed in Online supplement 1 . These results were combined with preexisting data from the MERN, using the same methods at the same laboratory, for a total of 121 analyses of volcanic rocks. Five outliers were excluded from the geochemical plots as these samples plotted beyond the range of the geochemical graphs and did not conform to the geochemical groupings defined in this study. Nine samples that were below $0.7 \mathrm{ppm} \mathrm{Nb}$ (quantification limit) were not included in the plots using $\mathrm{Nb}$.

The Archean crustal pole average (AC) is plotted on all geochemical diagrams (after Rudnick and Fountain, 1995) to examine the possibility of crustal contamination for the Colomb-Chaboullié magmas. However, as this is a global average, it is not representative of the possible contamination conditions for these magmas. As a result, fields are also included on these diagrams for the Lac Rodayer pluton $(\mathrm{n}=18)$ and the Théodat Complex $(\mathrm{n}=13)$ in the Opatica Subprovince. The Arod 2 and Arod3 units of the Lac Rodayer were used to determine the degree of contamination as these were the most spatially abundant bodies adjacent to the Colomb-Chaboullié belt, whereas Athel to Athe4 of the Théodat Complex were used as this was the lithogeochemical data available. Instead of averaging all of these samples from the potential contaminant lithologies, we drew fields comprising $80 \%$ of the data to show representative trends without visually overloading the plots.

The Lac Marcaut outcrop, located at $316632 \mathrm{~m} \mathrm{E}$ and 5 $662111 \mathrm{~m} \mathrm{~N}$ (UTM Nad 83 zone 18), was mapped in more detail using the tape and compass method to establish the relationship between the massive sulphide lens and the surrounding host basalts.

\section{Results}

\subsection{Lithofacies and petrography}

Volcanic rocks in the study area (Fig. 2) consist of: (1) the predominant pillowed to massive submarine basalt lavas (Acchl in Bandyayera and Daoudene, 2017), (2) variably porphyritic intermediate lava flows ( \pm intrusions?) (Acch2 and Acch2a), and (3) felsic to intermediate volcaniclastic rocks (Acch3). Due to the low density of outcrops in the study area, inter-units contacts were generally not observed. The pillowed facies dominates the basalt lavas (Figs. 3a and b), with variably deformed pillows ranging in length from $30 \mathrm{~cm}$ to $2 \mathrm{~m}$. Where primary textures are best preserved, hyaloclastite is recognised between the pillows, and consists of angular shards of former glass, now chloritised. Garnets $(>5 \mathrm{~mm}$ ) and disseminated sulphides are often present in the inter-pillow material. The lack of sufficiently well-preserved pillow shapes prevents stratigraphic younging direction from being determined. Schistose rocks are present in the most deformed areas of the stratigraphy. These fine-grained basalts have a plagioclase-amphibole \pm biotite \pm chlorite \pm epidote \pm opaques mineral assemblage (Figs. $3 \mathrm{c}$ and d).

Acch2 is a porphyritic andesite, which forms massive lava flows and/or subvolcanic intrusions in the eastern sector of the Colomb-Chaboullié belt (Fig. 2). These rocks are plagioclase-phyric (ca. 20\%), with tabular phenocrysts ranging in size from 3 to $5 \mathrm{~mm}$ (Figs. $3 \mathrm{e}$ and $\mathrm{f}$ ). Glomerophenocrysts of hornblende and lesser biotite are also present (5-8\%, 3-5 mm). The groundmass is recrystallised and composed of plagioclase-quartzamphibole \pm biotite \pm chlorite. Acch $2 a$ is characterised by pillowed andesite flows (Fig. 4a), containing a lower proportion of phenocrysts $(0-10 \%)$. The pillows are deformed and measure up to $1 \mathrm{~m}$ in length. At microscopic scale, plagioclase phenocrysts comprise $<5 \%$ of the composition of Acch2a, with an absence of hornblendebiotite glomerophenocrysts. This unit often shows a weak schistosity, defined by the alignment of elongate amphibole and biotite crystals, and in some cases chlorite. The groundmass mineral assemblage is comparable to that of Acch2.

Acch 3 comprise intermediate to felsic tuffs and lapilli tuffs (Bandyayera and Daoudene, 2017). This lithofacies occurs as lenses within the basalt lavas (Fig. 2). Some Acch3 rocks are finely bedded with well-developed centimetre to sub-centimetre stratification (Figs. $4 \mathrm{~b}$ and c), where plagioclase-rich bands alternate with thinner bands rich in chlorite. Where lapilli are present, they are elongate (Fig. $4 d)$. These volcaniclastic rocks comprise a plagioclasequartz \pm muscovite \pm chlorite \pm biotite mineral assemblage, with chlorite-rich bands also present at microscopic-scale in the laminated unit (Fig. 4c). 


\subsection{Lithogeochemistry}

Assessment of hydrothermal alteration

The majority of the samples were taken from the least altered parts of the volcanic rocks, and only a few samples were taken near mineralised areas. The extent to which rocks in the study area have been affected by hydrothermal alteration or diagenesis is assessed using the alteration box plot from Large et al. (2001) (Fig. 5a). This plot uses two indices, the Ishikawa alteration index (AI) from Ishikawa et al., 1976) and the chlorite-carbonate-pyrite index (CCPI) of Large et al. (2001). The AI measures the extent of sericite and chlorite alteration whereas the CCPI reveals the abundances of chlorite, $\mathrm{Fe}-\mathrm{Mg}$ carbonates (ankerite, dolomite and siderite), and pyrite. Most of the analyses on this diagram show minimal alteration.

\section{Geochemical groupings}

Geochemistry allows the basalts to be sub-divided into three major groups (Acchla, Acchlb and Acchlc) and two minor groups (Acchld and Acchle) (Table 1, Figs. 6 to 8). This division is based primarily on their extended multi-element profiles (Fig. 7), and these groups were then verified using the various classification, magmatic affinity, immobile trace element, and tectonic discrimination diagrams, in particular the Ross and Bédard (2009) diagram, the $\mathrm{TiO}_{2}$ vs $\mathrm{Zr}$ bivariate plot, the Wood (1980) diagram, and the Pearce (2008) plot (Figs. 6 and 8).

The Acchla basalts are defined by their relatively flat extended multi-element patterns, tholeiitic affinity and lower $\mathrm{Th} / \mathrm{Yb}$ ratios. Acchlb basalts are characterised by their more inclined multi-element pattern, with a small $\mathrm{Nb}$ Ta negative anomaly and intermediate Th contents. Acchlc rocks have the lowest $\mathrm{TiO}_{2}$ values of all the ColombChaboullié basalts, which is also reflected in their high $\mathrm{Zr} / \mathrm{TiO}_{2}$ ratios. They have the highest $\mathrm{Th}$ values and largest $\mathrm{Nb}$-Ta negative anomalies of all the basalts. Acchld basalts are defined by very high $\mathrm{TiO}_{2}$ contents and Acchle appear more intermediate in composition than other basalt groups, with higher $\mathrm{Zr}$ concentrations and $\mathrm{Nb} / \mathrm{Y}$ ratios. The basalts are further described below.

The intermediate lava groups (Acch2 and Acch2a) are similar to each other in terms of geochemical properties, however their division is based upon phenocryst populations. The volcaniclastic rocks are separated based on their composition, i.e. intermediate (Acch3a) and felsic (Acch3b).

\section{Harker diagrams}

There is relatively low dispersal of the data on the Harker diagrams (Fig. 5), which therefore allows these diagrams to be used petrologically, except for $\mathrm{K}$ and $\mathrm{Na}$ (Figs. $5 \mathrm{~g}$ and $\mathrm{h}$ ). Harker diagrams show that overall, when $\mathrm{SiO}_{2}$ increases, $\mathrm{TiO}_{2}, \mathrm{Fe}_{2} \mathrm{O}_{3}, \mathrm{MgO}$, and $\mathrm{CaO}$ decrease in concentration (Fig. 5). Harker diagrams show different trends amongst the mafic, intermediate, and felsic units. The mafic samples have flat $\mathrm{Al}_{2} \mathrm{O}_{3}$ concentrations and decreasing $\mathrm{Fe}_{2} \mathrm{O}_{3}, \mathrm{MgO}$ and $\mathrm{CaO}$ values. $\mathrm{TiO}_{2}$ is variable in the mafic rocks: different subunits behave differently (Fig. 5c).

The intermediate lavas and $A c c h 3 a$ also have $\mathrm{Fe}_{2} \mathrm{O}, \mathrm{MgO}$ and $\mathrm{CaO}$ decreasing when $\mathrm{SiO}_{2}$ increases, but with more gentle slopes compared to the mafic samples. Note that for $\mathrm{MgO}$, the least evolved intermediate samples have higher values than the most evolved mafic samples. $\mathrm{Al}_{2} \mathrm{O}_{3}$ is flat in the intermediate samples, whereas $\mathrm{TiO}_{2}$ decreases. $A c c h 3 b$ rocks have the highest silica contents, and have the smallest range in $\mathrm{TiO}_{2}, \mathrm{Fe}_{2} \mathrm{O}_{3}, \mathrm{MgO}$, and $\mathrm{CaO} . \mathrm{Al}_{2} \mathrm{O}_{3}$ decreases when silica increases in these rocks.

\section{Classification and magmatic affinity}

Both Winchester and Floyd (1977) classification diagrams are used here, rather than the total alkali-silica (TAS) diagram, to classify the Colomb-Chaboullié volcanic rocks. Although the geochemical samples used for this study are relatively fresh (Fig. 5a), the alkali elements used in the TAS diagram are mobile and therefore not ideal for rocks of Archean age.

All the mafic samples are dominantly sub-alkaline basalts (Fig. 6a) and plot at the boundary between the sub-alkaline basalt and andesite/basalt fields of figure $6 \mathrm{~b}$. However, some of the Acchlc samples have higher silica contents and therefore plot in the andesite/basaltic andesite field of figure 6a. This might be due to some silica mobility. Acchlc has a slightly elevated average $\mathrm{Zr} / \mathrm{TiO}_{2}$ ratio compared with the other two major basalt groups (Table 2), and is therefore slightly offset from the other mafic samples (Fig. 6b). Acchld plots with the principal mafic groups whereas Acchle has higher $\mathrm{Nb} / \mathrm{Y}$ ratios and dominantly plots with Acch2, Acch2a, and Acch3a (Fig. $6 b)$.

Acch 2 and Acch $2 a$ dominantly plot in the andesite/basaltic andesite field of figure $6 \mathrm{a}$ and in the andesite field of figure $6 \mathrm{~b}$. These samples also show a variation in their $\mathrm{SiO}_{2}$ content, but are densely clustered together when $\mathrm{Zr} / \mathrm{TiO}_{2}$ is compared with $\mathrm{Nb} / \mathrm{Y}$. Acch2 and Acch2a plot as a separate group to the mafic rocks due to their higher $\mathrm{Nb} / \mathrm{Y}$ ratios (Fig. 6b).

The Acch $3 a$ unit (intermediate volcaniclastic samples) plots with Acch2 and Acch2a (intermediate lavas) on the Winchester and Floyd (1977) diagrams. This therefore shows that Acch3a rocks are more intermediate in composition compared to Acch $3 b$. The latter represent felsic volcaniclastic rocks which have high silica contents (66.3 to 80.5 wt. \%) (Fig. 6a), with seven samples plotting in the rhyodacite/dacite field and five samples plotting in the rhyolite field. In figure $6 \mathrm{~b}$, these samples solely plot in the rhyodacite/dacite to andesite fields due to relatively low $\mathrm{Zr}$, as is typical of calc-alkaline felsic rocks. 
On the alkali-total iron-magnesium (AFM) diagram (Fig. $6 \mathrm{c})$, the basaltic samples dominantly plot in the tholeiitic field. This tholeiitic affinity is also observed on the Ross and Bédard (2009) magmatic affinity diagram for Acchla and Acchld (Fig. 6d). This particular diagram allows for the discrimination of rocks with a transitional magmatic affinity. Acchlb, Acchlc, and Acchle are transitional in affinity. All the intermediate lavas (Acch2 and Acch2a) and intermediate to felsic volcaniclastic rocks (Acch3a and $A c c h 3 b)$ are calc-alkaline.

On a $\mathrm{TiO}_{2}$ vs $\mathrm{Zr}$ diagram (Fig. 6e), most mafic samples from the Colomb-Chaboullié belt follow the positive slope of the tholeiitic trend, as titanium is initially incompatible in these magmas (Barrett and MacLean, 1999). However, Acchlc is characterised by low $\mathrm{TiO}_{2}$ concentrations (Fig. $6 e$, Table 1), and as a result clusters at the base of the tholeiitic trend. If the intermediate to felsic samples were related to the mafic samples by simple fractionation, they would be expected to plot along the same trend, ending in very low Ti but very high $\mathrm{Zr}$ values typical of tholeiitic rhyolites (e.g., rocks from the Matagami or Chibougamau areas in the Abitibi Greenstone Belt, MacLean and Barrett, 1993; Debreil, 2014; Boulerice, 2016). Instead, they follow a separate trend which parallels that of modern calcalkaline arc rocks. Note however that $A c c h 3 b$ samples have a similar range of $\mathrm{Zr}$ values to the intermediate samples but consistently lower Ti, which suggests that $A c c h 3 b$ is not simply related by fractionation to the intermediate magmas.

Trace elements in mafic lavas (Acchla to Acchle) On the extended trace element diagrams, Acchla has a relatively flat profile (Figs. 7a and e). The profiles are slightly more inclined for Acchlb and Acchlc. Acchlb demonstrates a slightly negative heavy rare earth element (HREE) slope whereas Acchlc shows a flat to slightly positive HREE slope (Figs. $7 b$ and c). Small negative NbTa anomalies occur for these two basalt groups. In terms of profiles, Acchld is most similar to Acchla, whereas Acchle is most similar to Acchlb (Fig. 7d). Acchla and the two minor basalt groups straddle the MORB and volcanic arc (IAB or VAB) fields on the Agrawal et al. (2008) and Wood (1980) diagrams (Fig. 8a and b). Acchlb and Acchlc plot in the IAB and VAB fields. On the Pearce (2008) diagram, Acchla plots just above the N-MORB pole (Fig. 8c). Acchlb, Acchlc, and Acchle have higher $\mathrm{Th} / \mathrm{Yb}$ ratios and are situated above the MORB-OIB array.

\section{Andesite trace elements (Acch2 and Acch2a)}

Extended trace element diagrams for Acch2 and Acch $2 a$ show notable $\mathrm{Nb}$-Ta and Ti negative anomalies (Figs. 9a and b), which are much more evident than in the basalt samples. Acch 2 and Acch $2 a$ both show light rare earth element (LREE) enrichment. The geochemical similarity between these two intermediate lava units is demonstrated by their comparable trace element profiles.
These andesites plot in the volcanic arc fields on tectonic discrimination diagrams (Figs. 8a and b). On the Pearce (2008) diagram, the andesites plot well outside the MORBOIB array, near the Archean crustal pole and possible contaminants from the Opatica Subprovince (Fig. 8c).

Intermediate to felsic volcaniclastic rocks (Acch3a and Acch3b)

The intermediate volcaniclastic rocks $(A c c h 3 a)$ are chemically similar to the andesite lavas on all diagrams (Figs. 6a to e, Figs. 8a to c, and Fig. 9c), suggesting that these units are related.

A total of 12 felsic volcaniclastic rocks from the ColombChaboullié greenstone belt (Acch3b) were analysed and positioned on the Hart et al. (2004) felsic volcanic rock classification diagram (Fig. 8d). These samples dominantly plot at the boundary between the FI and FII domains (Hart et al., 2004), alongside the Opatica Subprovince contaminants. The extended multi-element diagram (Fig. 9d) once again shows the distinctive $\mathrm{Nb}-\mathrm{Ta}$ and $\mathrm{Ti}$ negative anomalies.

\subsection{Mineralisation}

Five showings are present in the basalt lavas, one in the volcaniclastic unit, and one in a sedimentary sequence (see Fig. 2). Sulphide mineralisation forms disseminated sulphides, veins, and massive to semi-massive manifestations. In the pillowed basalts, the sulphides are present within the inter-pillow material (Fig. 10a), often associated with chlorite and garnet alteration in the pillow margins (Fig. 10b). In the massive basalt flows, the sulphides are controlled by fractures, forming stockworkstyle veins (Fig. 10c). Three massive to semi-massive bodies are identified in this greenstone belt, including the Lac Marcaut lens (Fig. 10d). These contain rounded, silicarich clasts containing minor pyrite and chalcopyrite, in a pyrrhotite-rich matrix (Figs. 10e and f). These clasts may also comprise small chlorite clasts and irregular felsic fragments. The main $\mathrm{Au}-\mathrm{Ag}-\mathrm{Cu}$ showings of the ColombChaboullié belt are situated close to lithological contacts, whether contacts are between lithological units (e.g., mafic-felsic) or internal contacts between basaltic subunits (Fig. 11).

The Lac Marcaut outcrop was mapped in more detail as a typical example (Fig. 11). This outcrop consists mostly of two types of basalts, Acchla and Acchlc, with the sulphide lens at the contact. Acchla is composed of both pillowed and schistose units. Sulphide mineralisation is located in the schistose unit as rusty patches and thin sulphide veins. Acchlc is dominantly composed of deformed pillows. Sulphide patches are also present in this facies, along with disseminated sulphides in the inter-pillow material. The main sulphide lens has a maximum thickness of $1.4 \mathrm{~m}$ and can be followed laterally for $80 \mathrm{~m}$ along an outcrop ridge (Thorsen et al., 1993). Grab samples within this lens yield up to $27 \mathrm{~g} / \mathrm{t}$ gold (Thorsen et al., 1993). The schistosity of 
the host basalt lies at a slight angle relative to the sulphide lens (Fig. 11, inset).

\section{Discussion}

\subsection{Mode of emplacement for volcanic rocks}

The presence of pillowed basalt and pillowed andesite lava flows, along with hyaloclastites, indicates that the volcanic rocks of the Colomb-Chaboullié greenstone belt were deposited in a submarine setting. As the intermediate to felsic volcaniclastic rocks form lenses within the basalt flows, these were also most likely formed in the same submarine environment. The detailed mode of emplacement of the volcaniclastic rocks has not been investigated given the small number of outcrops available, the relatively high metamorphic grade, and penetrative tectonic deformation.

\subsection{Mineralisation}

We interpret the Au-Ag-Cu sulphide showings of the belt as synvolcanic (VMS-style) for the following reasons:

- sulphide lenses occur at or near geological contacts;

- chlorite alteration (some of which has recrystallized as garnet) is common;

- within pillow lavas, sulphides replace the inter-pillow material, indicating that primary porosity was still available when hydrothermal fluid circulation occurred;

- in the massive basalt facies, disseminated sulphides infill fractures forming a stockwork with chlorite and garnet, which is also a typical feature of volcanogenic mineralisation (Galley et al., 2007).

At the Lac Marcaut showing, the massive sulphide lens sits at a contact between Acchla and Acchlc mafic lavas. The same contact may be prospective elsewhere in the ColombChaboullié belt.

\subsection{Geographic distribution of geochemical groups}

The principal (Acchla, Acchlb, and Acchlc) and minor (Acchld and Acchle) basalt groups were identified using their extended multi-element profiles, which were confirmed using major oxide concentrations, magmatic affinity, incompatible elements such as Th, and elemental ratios such as $\mathrm{Zr} / \mathrm{TiO}_{2}$ and $\mathrm{Th} / \mathrm{Yb}$ (Table 1, Figs. 5 to 8). The dominant Acchla basalt unit is distributed throughout the Colomb-Chaboullié greenstone belt (Fig. 2). Acch1b occurs in the western sector of the map. Acchlc occurrences are located in the central portion of the greenstone belt, dominantly to the south of Acchla samples. Acchld is defined by three samples which all occur in the far east of the map within a $1.6 \mathrm{~km}-$ long band, in a well-developed pillowed unit. Although Acchld and Acchle are both defined by only three samples, they have been included here because they are chemically distinct from the rest of the mafic samples.

The intermediate lava flow units (Acch2 and Acch2a), distinguished from one another based on phenocryst populations (section 4.1), are geochemically similar to each other. Based on the present geochemical dataset, a number of small, isolated Acch $2 a$ units have been identified in the mafic lava flows. These small intermediate lava lenses are located adjacent to Acch3 lenses, or close to a contact with the felsic plutonic rocks of the Opatica Subprovince. Acch 3 has been divided here into Acch $3 a$ and Acch $3 b$ based on the differing geochemistry (intermediate versus felsic).

\subsection{Petrology}

The volcanic and volcaniclastic rocks of the ColombChaboullié greenstone belt have compositions ranging from basalts to rhyolites (Figs. 6a and b). The basalts are tholeiitic to transitional in magmatic affinity whereas all intermediate and felsic rocks are calc-alkaline (Figs. 6c to e), therefore we discuss these rocks separately.

\section{Basalts}

The tholeiitic to transitional basaltic rocks of the ColombChaboullié belt have high iron concentrations, with a maximum of 18.2 wt. \% $\mathrm{Fe}_{2} \mathrm{O}_{3}$ (Fig. 5d). Overall, Acchla samples show high $\mathrm{Al}_{2} \mathrm{O}_{3}, \mathrm{Fe}_{3} \mathrm{O}_{3}$ and relatively high $\mathrm{MgO}$ concentrations (Figs. 5b, d, and e). Trace elements are somewhat similar to those of modern N-MORB, although the Th values are higher than those of N-MORB, the LREE have a flatter pattern and some samples have a negative Ti anomaly (Fig. 7a). Within tectonic discrimination diagrams, Acchla samples dominantly plot in the MORB fields (Figs. 8a and b). This suggests that this basaltic unit comes from a mantle source somewhat similar to that of modern N-MORB. Acchlb and Acchlc have higher Th contents than Acchla (Figs. 7b and c), so plot in the arc fields on the tectonic discrimination diagrams (Figs. 8a and b). Acchlb and Acchlc also plot further away from the MORB-OIB array, with higher $\mathrm{Th} / \mathrm{Yb}$ ratios (Fig. 8c).

On the Pearce (2008) diagram, the Acchla through to Acchlb and Acchlc progression appears to form an assimilation-fractional crystallisation (AFC) trend that also extends to the andesites. Although it is tempting to assign all of the Colomb-Chaboullié volcanic rocks, from mafic through to felsic, to this AFC trend, the basaltic rocks are not a product of AFC. Acchlc is the most primitive basaltic unit based on low $\mathrm{Zr}$ and low $\mathrm{TiO}_{2}$ (Fig. 6e). Compared to Acchla, Acchlb and Acchlc also have higher average $\mathrm{MgO}$ contents (Table 1). Yet Acchlb and Acchlc show a higher degree of crustal contamination based on trace elements such as Th (e.g., Fig. 8b), and on their position on the Pearce (2008) plot (Fig. 8c). This suggests that rather than AFC producing the basalts of the ColombChaboullié, fractionation and crustal contamination occurred mostly independently. We propose that crystal fractionation explains most of the major element variations in the basalts (hence the tholeiitic trend on the $\mathrm{TiO}_{2}-\mathrm{Zr}$ diagram) while a negligible to moderate amount of crustal contamination (Tomlinson and Condie, 2001), largely independent of crystal fractionation, would explain most of 
the trace elements trends. Perhaps the basalts only experienced crustal contamination during ascent, with $A c c h 1 b$ and Acchlc experiencing the highest degree of contamination of the basalts.

Alternatively, the steep progression observed on the Pearce (2008) diagram for the basalts could also be explained by a subduction component, if subduction occurred in the Archean. However, as the intermediate to felsic rocks are thought to be strongly influenced by crustal contamination (see below), a certain degree of crustal contamination should have also affected the basalts which were generated at the same time. So we prefer the crustal contamination explanation to the idea of subduction enrichment for the basalts.

\section{Andesitic lavas and intermediate volcaniclastic rocks} Beyond the more evolved compositions, the andesitic lavas (Acch2 and Acch2a) and intermediate to felsic volcaniclastic rocks (Acch $3 a$ and Acch $3 b$ ) are chemically very different from the basalts. These differences include their higher $\mathrm{Nb} / \mathrm{Y}$ ratios (Fig. 6b), their calc-alkaline tendency on the $\mathrm{TiO}_{2}$ versus $\mathrm{Zr}$ diagram (Fig. 6e), and their "volcanic arc" signature illustrated by their pronounced $\mathrm{Nb}-\mathrm{Ta}$ and Ti negative anomalies (Figs. 9a to d). Harker diagrams show that the most $\mathrm{SiO}_{2}$-rich basalts have lower $\mathrm{MgO}$ concentrations than the most $\mathrm{SiO}_{2}$-poor andesites, and therefore have separate trends (Fig. 5e) and a different evolutionary history. The intermediate lavas and intermediate to felsic volcaniclastic rocks are intercalated with the basalts; both the basalts and andesite are lavas; and some of the volcaniclastic rocks are coarse, suggesting they are relatively proximal, and derived from a local vent. This means that we need to generate all of these rocks in a limited geographic area, and assigning a different tectonic environment to the basalts versus the andesites and more evolved rocks is not a good solution.

There is ample evidence for crustal contamination of the intermediate and felsic rocks of the Colomb-Chaboullié greenstone belt. This contamination trend is seen across all geochemical diagrams used in this study. For the intermediate rocks (lavas and volcaniclastic), the trace and major element variations we see in the database can be mostly explained by increasing AFC, hence the calcalkaline trend (Figs. 5, 6e, 8c). These intermediate magmas might have spent a much longer time in the crust than the basalts, and may have been erupted due to the injection of fresh mafic magma into a pre-existing magma chamber (Fig. 12). This mixing of a mafic melt with more evolved melts was observed during the 2010 Eyjafjallajökull eruption in Iceland, which produced mafic, intermediate, and silicic compositions over only a few months (Sigmarsson et al., 2011; Tawasewicz et al., 2012). This model works regardless of the tectonic style during the Archean and the specific tectonic setting of the ColombChaboullié belt, on which we do not wish to speculate here.
The Colomb-Chaboullié intermediate rocks commonly extend beyond the Archean crustal pole (Figs. 8a to c), so the andesites could have been contaminated by a composition richer in Th than the average Archean crust value. Both the Lac Rodayer pluton and the Théodat Complex, located south of the greenstone belt in the Opatica Subprovince, can be suitable contaminants from a geochemical point of view (Figs. 5, 6, 8, 9).

\section{Felsic volcaniclastic rocks}

In terms of major elements, some Acch $3 b$ samples plot outside the Lac Rodayer and Théodat Complex contamination fields and have higher $\mathrm{SiO}_{2}$ concentrations. Two of the felsic samples which plot towards the sericite pole on the alteration box plot (Fig. 5a) show high $\mathrm{SiO}_{2}$ abundances in the Harker diagrams, indicating that silicification and sericitization may play a part in the evolution of these felsic rocks. These two samples also have low Na concentrations (Fig. 5h), which is typical of high-temperature VMS-related alteration.

Acch $3 b$ samples are located at the boundary between the FI and FII domains (Hart et al., 2004; Fig. 8d), which suggests that these rocks originated from a deep source. Alternatively, the high pressure signature may be explained by the partial melting of a garnet \pm amphibolerich metabasaltic source which would produce felsic magmas depleted in HREE and Y. This high pressure signature may be inherited from magmatic processes that are much older than the Colomb-Chaboullié greenstone belt.

\section{Conclusions}

In this paper, the stratigraphy, volcanology, and geochemistry of the volcanic units of the ColombChaboullié greenstone belt in the James Bay area of Quebec were refined and interpreted. Pillowed and massive basaltic flows are dominant. They alternate with variably porphyritic, pillowed and non-pillowed andesitic flows as well as intermediate to felsic volcaniclastic rocks. The pillowed facies and hyaloclastite material indicates that these rocks were emplaced in a submarine environment. A number of $\mathrm{Au}-\mathrm{Ag}-\mathrm{Cu}$ sulphide showings are known in the belt and were shown to have a synvolcanic origin.

Five types of basalts have been defined geochemically, including three major units. Acchla rocks are most similar to MORB, whereas Acchlb and Acchlc samples show progressively more contaminated geochemical signatures. The major element trends for the basalts are mostly explained by crystal fractionation, not by AFC. In contrast, Acch 2 and Acch $2 a$ (intermediate lavas), Acch $3 a$ (intermediate volcaniclastic rocks), and Acch $3 b$ (felsic volcaniclastic rocks) share geochemical properties, including major elements, with possible contaminants from the Opatica Subprovince. As these intermediate to felsic rocks are interstratified with the basalt flows, we propose 
that the former were produced via crustal contamination and mixing processes within a pre-existing magma chamber. The basalts on the other hand had a more direct passage from the mantle to the surface. Our model works regardless of the prevailing tectonic style during the Archean, and may be applicable to other greenstone belts.

\section{Acknowledgements}

M. R.-Laflèche and J. O'Neil are thanked for reviewing the MSc thesis of the first author, from which this paper is derived. This work was supported with funding from the Ministère de l'Énergie et des Ressources naturelles (Québec). Journal reviewers J. Pearce and P. Thurston are acknowledged for constructive comments.

\section{Data availability}

All whole-rock geochemical data is included in Online Supplement 2.

\section{References}

Agrawal S, Guevara M, Verma SP (2008) Tectonic discrimination of basic and ultrabasic volcanic rocks through log-transformed ratios of immobile trace elements. International Geology Review 50: 1057-1079

Almberg LD, Larsen JF, Eichelberger JC, Vogel Ta, Patino LC (2008) Comparison of eruptive and intrusive samples from Unzen Volcano, Japan: Effects of contrasting pressure-temperature-time paths. Journal of Volcanology and Geothermal Research 175: 60-70

Altigani MAH, Merkle RKW, Dixon RD (2016) Geochemical identification of episodes of gold mineralisation in the Barberton Greenstone Belt, South Africa. Ore Geology Reviews 75: 186-205

Aoki A, Shuto K, Itaya T (1999) Stratigraphy and K-Ar ages of Tertiary volcanic rocks in the Hamamasu area northweatern Hokkaido, Japan. Journal of the Geological Society of Japan 105: 341-351

Arndt NT, Lesher CM, Czamanske GK (2005) Mantle-derived magmas and magmatic Ni-Cu-(PGE) deposits. Economic Geology $100^{\text {th }}$ Anniversary Volume: 5-23

Bandyayera D, Daoudene Y (2017) Geologie de la Region du Lac Rodayer (SNRC 32K13-32K14-32N03 et 32N04-SE). Ministère des Ressources naturelles, Québec; report RG 2017-01, $57 \mathrm{p}$.

Barrett TJ, MacLean WH (1999) Volcanic sequences, lithogeochemistry, and hydrothermal alteration in some bimodal volcanic-associated massive sulfide systems. In: Barrie CT, Hannington Md (eds) Volcanic-associated massive sulfide deposits: processes and examples in modern and ancient settings Society of Economic Geologists, Reviews in Economic Geology 8: 101-131

Bédard JH, Harris LB (2014) Neoarchean disaggregation and reassembly of the Superior craton. Geology 42: 951-954

Bédard JH, Harris LB, Thurston PC (2013) The hunting of the snArc. Precambrian Research 229: 20-48

Benn K, Moyen JF (2008) The Late Archean Abitibi-Opatica terrane, Superior Province; A modified oceanic plateau. In: Condie KC, Pease V (eds) When Did Plate Tectonics Begin on Planet Earth? Geological Society of America, Special Paper 440: 173-197

Boily M, Dion C (2002) Geochemistry of boninite-type volcanic rocks in the Frotet-Evans greenstone belt, Opatica subprovince, Quebec: implications for the evolution of
Archaean greenstone belts. Precambrian Research 115: 349-371

Boulerice A (2016) Volcanology of the Lemoine Member of the Waconichi Formation, Abitibi Subprovince, Chibougamau, Quebec. Unpublished MSc thesis, Institut National de la Recherche Scientifique, Centre Eau Terre Environnement, Québec, 193 p.

Card KD (1990) A review of the Superior Province of the Canadian Shield, a product of Archean accretion. Precambrian Research 48: 99-156

Card KD, Ciesielski A (1986) DNAG \#1. Subdivisions of the Superior Province of the Canadian Shield. Geoscience Canada 13: 5-13

Caté A, Mercier-Langevin P, Ross P-S, Duff S, Hannington MD, Dubé B, Gagné S (2015) Geology and Au enrichment processes at the Paleoproterozoic Lalor auriferous volcanogenic massive sulphide deposit, Snow Lake Manitoba. In: Peter JM, Mercier-Langevin P., ed., Targeted Geoscience Initiative 4: Contributions to the understanding of volcanogenic massive sulphide deposit genesis and exploration methods development:

Geological Survey of Canada, Open File 7853: 131-145

Condie KC (1981) Archean greenstone belts. Developments in Precambrian Geology, Vol. 3. Elsevier, Amsterdam, 434 p.

Davis WJ, Gariépy C, Sawyer EW (1994) Pre-2.8 Ga crust in the Opatica gneiss belt: A potential source of detrital zircons in the Abitibi and Pontiac subprovinces, Superior Province, Canada. Geology 22: 1111-1114

Davis WJ, Machado N, Gariépy C, Sawyer EW, Benn K (1995) $\mathrm{U}-\mathrm{Pb}$ geochronology of the Opatica tonalite-gneiss belt and its relationship to the Abitibi greenstone belt, Superior Province, Quebec. Canadian Journal of Earth Sciences 32: 113-127

Debreil JA (2014) Évolution volcanologique et chimicostratigraphique du district minier de matagami, Sousprovince de l'Abitibi, Québec. Unpublished PhD thesis, Institut National de la Recherche Scientifique, Centre Eau Terre Environnement, Québec, 279 p.

Ewart A, Bryan WB, Chappell BW, Rudnick RL (1994) Regional geochemistry of the Lau-Tonga arc and backarc systems. Proceedings of the Ocean Drilling Program, Scientific Results 135: 385-425

Franklin J, Gibson H, Jonasson I, Galley A (2005) Volcanogenic massive sulfide deposits. Economic Geology 100th Anniversary Volume: 523-560

Frolova TI, Plechov PY, Tikhomirov PL, Churakov SV (2001) Melt inclusions in minerals of allivalites of the KurilKamchatka island arc. Geochemistry International 39: 336-346

Galley AG, Hannington MD, Jonasson IR (2007) Volcanogenic Massive Sulphide Deposits. In: Goodfellow, W.D., ed., Mineral deposits of Canada: A synthesis of major deposit types, district metallogeny, the evolution of geological provinces, and exploration methods: Geological Association of Canada, Mineral Deposits Division, Special Publication No. 5: 141-161

Gifkins C, Herrmann W, Large R (2005) Altered volcanic rocks; a guide to description and interpretation. Centre for Ore Deposit Research, University of Tasmania, Australia, 275 p.

Goldfarb RJ, Baker T, Dubé B, Groves DI, Hart CJR, Gosselin P (2005) Distribution, character, and genesis of gold deposits in metamorphic terranes. Society of Economic 
Geologists, Economic Geology $100^{\text {th }}$ Anniversary Volume: 407-450

Groves DI, Goldfard RJ, Gebre-Mariam M, Hagemann SG, Robert F (1998) Orogenic gold deposits: A proposed classification in the context of their crustal distribution and relationship to other gold deposit types. Ore Geology Reviews 13: 7-27

Hart TR, Gibson HL, Lesher CM (2004) Trace element geochemistry and petrogenesis of felsic volcanic rocks associated with volcanogenic massive $\mathrm{Cu}-\mathrm{Zn}-\mathrm{Pb}$ sulfide deposits. Economic Geology 99: 1003-1013

Hocq M (1994) La Province du Supérier. In: Dubé C (ed) Géologie du Québec. Les publications du Québec: 7-20

Ishikawa Y, Sawaguchi T, Iwaya S, Horiuchi M (1976) Delineation of prospecting targets for Kuroko deposits based on modes of volcanism of underlying dacite and alteration halos (in Japanese with English abstract). Mining Geology 26: 105-117

Kerrich R, Polat A (2006) Archean greenstone-tonalite duality: Thermochemical mantle convection models or plate tectonics in the early Earth global dynamics? Tectonophysics 415: 141-165

Laflèche MR, Dupuy C, Bourgault H (1992) Geochemistry and petrogenesis of Archean mafic volcanic rocks of the southern Abitibi belt, Québec. Precambrian Research 57: 207-241

Large R, Gemmel B, Paulick H, Huston L (2001) The alteration box plot: a simple approach to understanding the relationship between alteration mineralogy and lithogeochemistry associated with volcanic-hosted massive sulfide deposits. Economic Geology 96: 957971

MacLean WH, Barrett TJ (1993) Lithgeochemical techniques using immobile elements. Journal of Geochemical Exploration 48: 109-133

Maier WD, Groves DI (2011) Temporal and spatial controls on the formation of magmatic PGE and Ni-Cu deposits. Mineralium Deposita 46: 841-857

Miyoshi M, Hasenaka T, Sano T (2005) Genetic relationship of the compositionally diverse magmas from Aso postcaldera volcanism. Bulletin of the Volcanoloical Society of Japan 50: 269-283

Miyoshi M, Fukuoka T, Sano T, Hasenaka T (2008) Subduction influence of Philippine Sea plate on the mantle beneath northern Kyushu, SW Japan : An examination of boron contents in basaltic rocks. Journal of Volcanology and Geothermal Research 171: 73-87

Miyoshi M, Furukawa K, Shinmura T, Shimono M, Hasenaka T (2009) Petrography and whole-rock geochemistry of preAso lavas from the caldera wall of Aso volcano, central Kyushu. Journal of the Geological Society of Japan 115: 672-687

Miyoshi M, Shimono M, Hasenaka T, Sano T, Mori Y, Fukuoka T (2010) Boron systematics of Hisatsu and Kirishima basaltic rocks from southern Kyushu, Japan. Geochemical Journal 44: 359-369

Moyen J-F, Laurent O (2018) Archean tectonic systems: A view from igenous rocks. Lithos 302-303: 99-125

O'Neil J, Francis D, Carlson RW (2011) Implications of the Nuvvuagittuq greenstone belt for the formation of Earth's early crust. Journal o Petrology 52: 985-1009

O’Neil J, Carlson RW, Paquette J-L, Francis D (2012) Formation age and metamorphic history of the Nuvvuagittuq greenstone belt. Precambrian Research 220-221: 23-44
O Neil J, Boyet M, Carlson RW, Paquette J-L (2013) Half a billion years of reworking of Hadean mafic crust to pruduce the Nuvvuagittuq Eoarchean felsic crust. Earth and Planetary Science Letters 379: 13-25

Pearce JA (2008) Geochemical fingerprinting of oceanic basalts with applications to ophiolite classification and the search for Archean oceanic crust. Lithos 100: 14-48

Percival J, Mortenson JK, Stern RA, Card KD (1992) Giant granulite terranes of northeastern Superior Province: the Ashuanipi complex and Minto block. Canadian Journal of Earth Sciences 29: 2287-2308

Polat A, Kerrich R (2001) Geodynamic processes, continental growth, and mantle evolution recorded in late Archean greenstone belts of the southern Superior Province, Canada. Precambrian Research 112: 5-25

Poulsen KH, Robert F, Dubé B (2000) Geological classification of Canadian gold deposits. Geological Survey of Canada, Bulletin 540, $106 \mathrm{p}$.

Powell WG, Carmichael DM, Hodgson CJ (1995) Conditions and timing of metamorphism in the southern Abitibi greenstone belt, Quebec. Canadian Journal of Earth Sciences 32: 787-805

Ross P-S, Bédard JH (2009) Magmatic affinity of modern and ancient subalkaline volcanic rocks determined from trace element discriminant diagrams. Canadian Journal of Earth Sciences 46: 823-839

Riopel J (1994) Rapport technique des travaux, campagne 1994, propriété Lac Marcaut. Statutory report submited by Cambiex Exploration to Ministère des Ressources naturelles, Québec, GM 53629, 328 p.

Rogers R, Ross P-S, Goutier J, Mercier-Langevin P (2014) Using physical volcanology, chemical stratigraphy, and pyrite geochemistry for volcanogenic massive sulfide exploration : An example from the Blake River Group, Abitibi Greenstone Belt. Economic Geology 109: 61-88

Rudnick RL, Fountain DM (1995) Nature and composition of the continental crust: A lower crustal perspective. Reviews of Geophysics 33: 267-309

Sawyer E, Benn K (1993) Structure of the high-grade Opatica Belt and adjacent low-grade Abitibi Subprovinces, Canada: an Archaean mountain-front. Journal of Structural Geology 15: 1443-1458

Sigmarsson O, Vlastelic I, Andreasen R, Bindeman I, Devidal JL, Moune S, Keiding JK, Larsen G, Höskuldsson A, Thordarson Th (2011) Remobilization of silicic intrusion by mafic magmas during the 2010 Eyjafjallajökull eruption. Solid Earth 2: 271-281

Smithies RH, Ivanic TJ, Lowery JR, Morris PA, Barnes SJ, Wyche S, Lu Y-J (2018) Two distinct origins for Archean greenstone belts. Earth and Planetary Science Letters 487: 106-116

Stolz AJ, Varne R, Davies GR, Wheller GE, Foden JD (1990) Magma source components in an arc-continent collision zone: The Flores-Lembata sector, Sunda Arc, Indonesia. Contributions to Mineralogy and Petrology 105: 585-601

Sun S-S, McDonough WF (1989) Chemical and isotopic systematics of oceanic basalts: implications for mantle composition and processes. In: Saunders AD, Norry MJ (eds) Magmatism in the Ocean Basins. Geological Society, London, Special Publication 42: 313-345

Takagi T, Orihashi Y, Naito K, Watanabe Y (1999) Petrology of a mantle-derived rhyolite, Hokkaido, Japan. Chemical Geology 160: 425-445

Tawasewicz J, White RS, Woods AW, Brandsdottir B, Gudmundsson MT (2012) Magma mobilization by 
downward-propagating decompression of the Eyjafjallajokull volcanic plumbing system. Geophysical Research Letters 39, L19309

Tomlinson KY, Condie KC (2001) Archean mantle plumes: Evidence from greenstone belt geochemistry. In: Ernst RE, Buchan KL, eds Mantle plumes: Their identification through time: Boulder, Colorado. Geological Society of America, Special Paper 352: 341-357

Thorsen K, Taquet B, Lamothe G, Burk R, Tarnocai D (1993) Assessment report on the 1991-1992 exploration program, Lac Marcaut property. Statutory report submitted by Teck Exploration Ltd. to Ministère des Ressources naturelles Québec. GM 52214, p. 231

Thurston PC, Ayer JA, Goutier J, Hamilton MA (2008) Depositional gaps in Abitibi Greenstone Belt stratigraphy: a key to exploration for syngenetic mineralization. Economic Geology 34: 677-680

Tsvetkov AA, Sukhanov MK, Govorov GI (1985) Regular evolution of magmatism in recent and Paleogene arcs (for instance Kuril Islands and northern Caucasus). In: Bogatikov OA, eds Oceanic magmatism: Evolution, geological correlation: Nauka, Moscow: 185-218

Westall F, de Ronde C. E. J, Southam G, Grassineau N, Colas M, Cockell C, Lammer H (2006) Implications of a 3.4723.333 Gyr-old subaerial microbial mat from the Barberton greenstone belt, South Africa for the UV environmental conditions on the early Earth. Philosophical Transactions of the Royal Society of London B: Biological Sciences 361: 1857-1876

Winchester JA, Floyd PA (1977) Geochemical discrimination of different magma series and their differentiation products using immobile elements. Chemical Geology 20: 325-343

Wood DA (1980) The Application of a Th-Hf-Ta diagram to problems of tectonomagmatic classification and to establishing the nature of crustal contamination of basaltic lavas of the British Tertiary volcanic province. Earth and planetary science letters 50: 11-30 


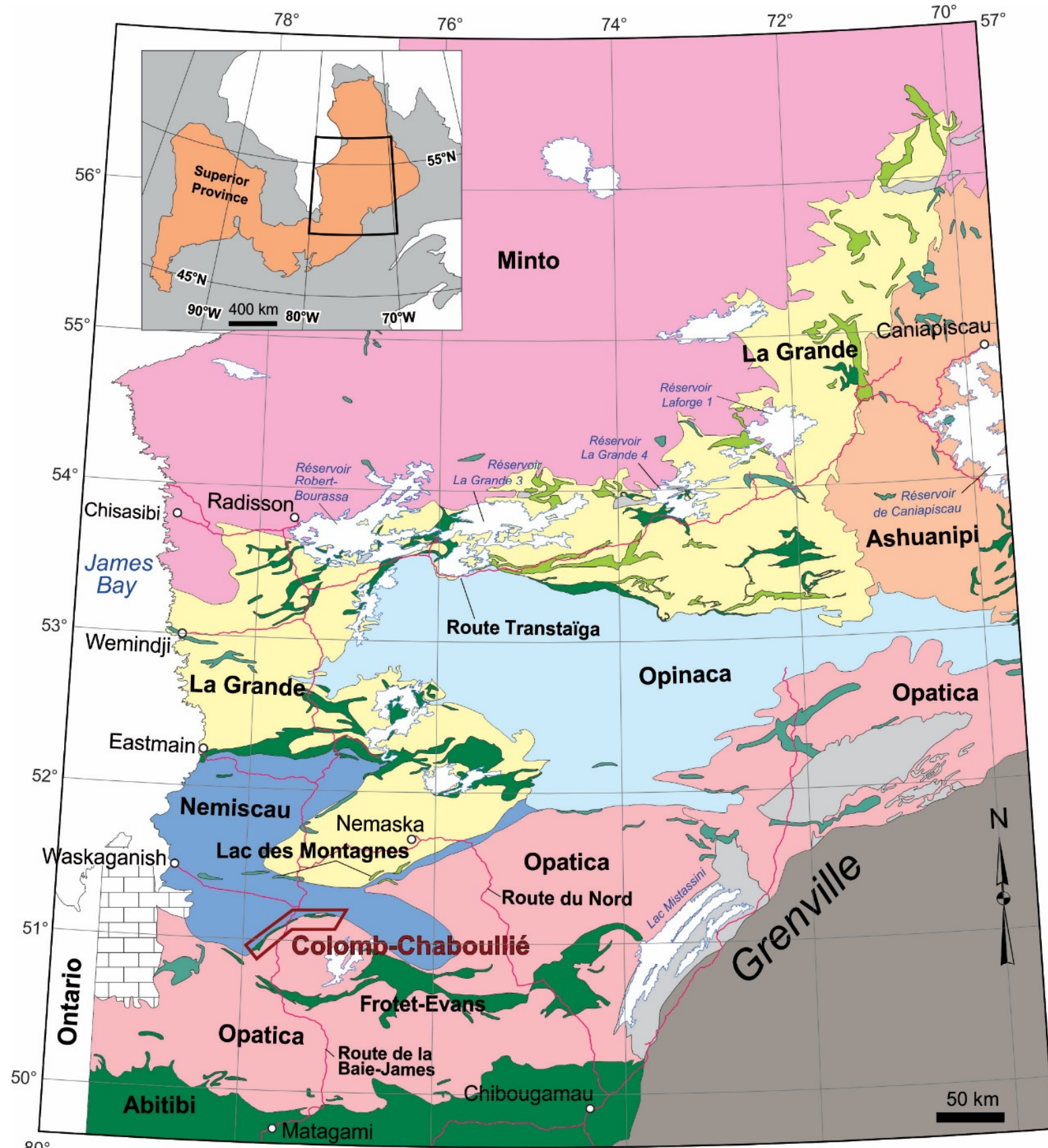

$80^{\circ}$

Subprovince type of the Eastern Superior Province

High-grade gneiss
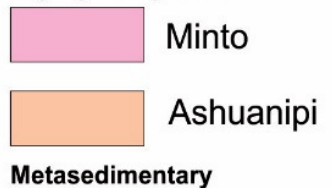

Plutonic

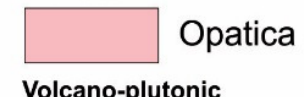

Archean volcano-sedimentary sequences
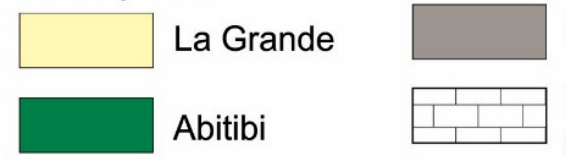

Undetermined age $\sim 2,7 \mathrm{Ga}$

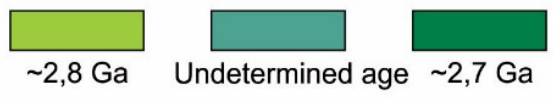

Post Archean sequences

Metasedimentary

Opinaca

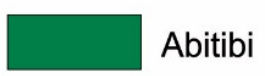

Grenville

Paleoproterozoic sequence

Nemiscau

Fig. 1 Geological map of the Eastern Superior Province, Quebec, showing the location of the Colomb-Chaboullié greenstone belt (in red) at the contact between the Opatica and Nemiscau subprovinces. After Bandyayera and Daoudene (2017). 

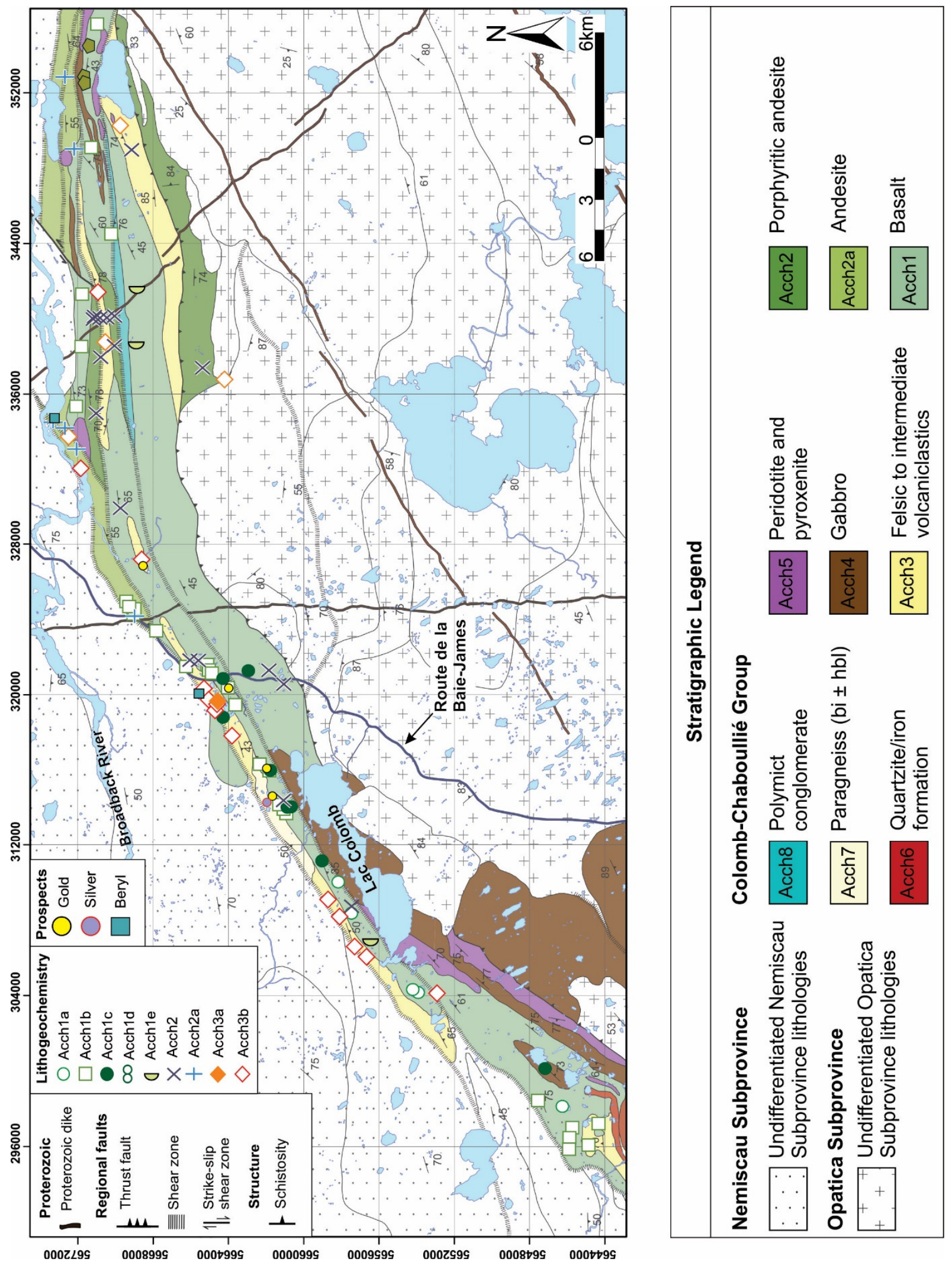

Fig. 2 Original geological map of the Colomb-Chaboullié greenstone belt. The geology of the study area, the stratigraphic position of the geochemical samples used in this study, and the locations of previously recorded mineralisation are shown (after Bandyayera and Daoudene, 2017). 

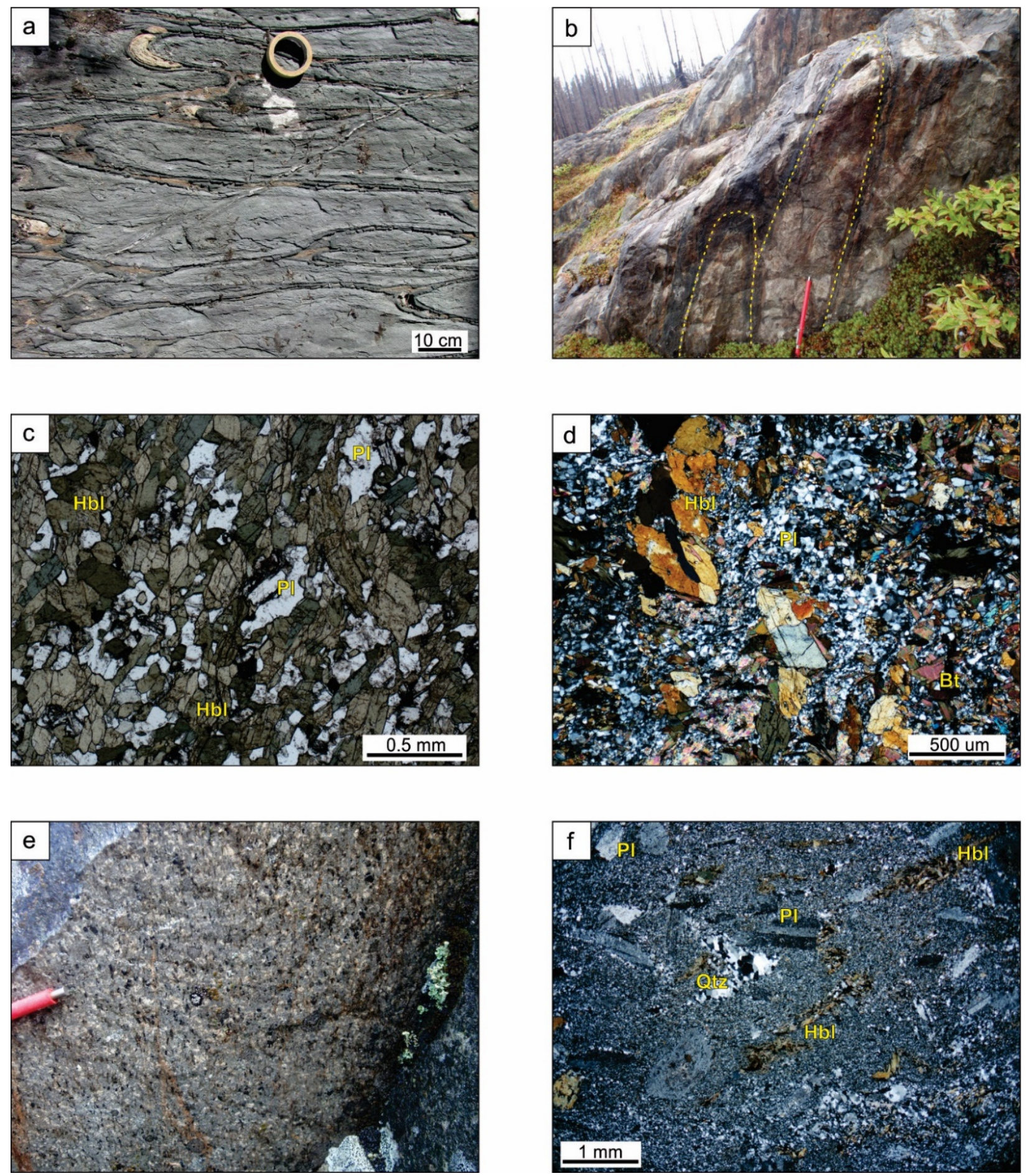

Fig. 3 Basaltic and andesitic lava flows of the Colomb-Chaboullié belt. (a) Best preserved pillows in the NE of the belt, (b) $3 \mathrm{D}$ view of highly deformed pillows, (c)-(d) photomicrographs of the basaltic lavas (plane polarized light and crosspolarized light, respectively). (e)-(f) Porphyritic andesite flows or subvolcanic intrusions in outcrop view and thin section (cross-polarized light). Abbreviations: $\mathrm{Bt}=$ biotite; $\mathrm{Hbl}=$ hornblende; $\mathrm{Pl}=$ plagioclase; $\mathrm{Qtz}=$ quartz. The red magnet is $12 \mathrm{~cm}-$ long. 

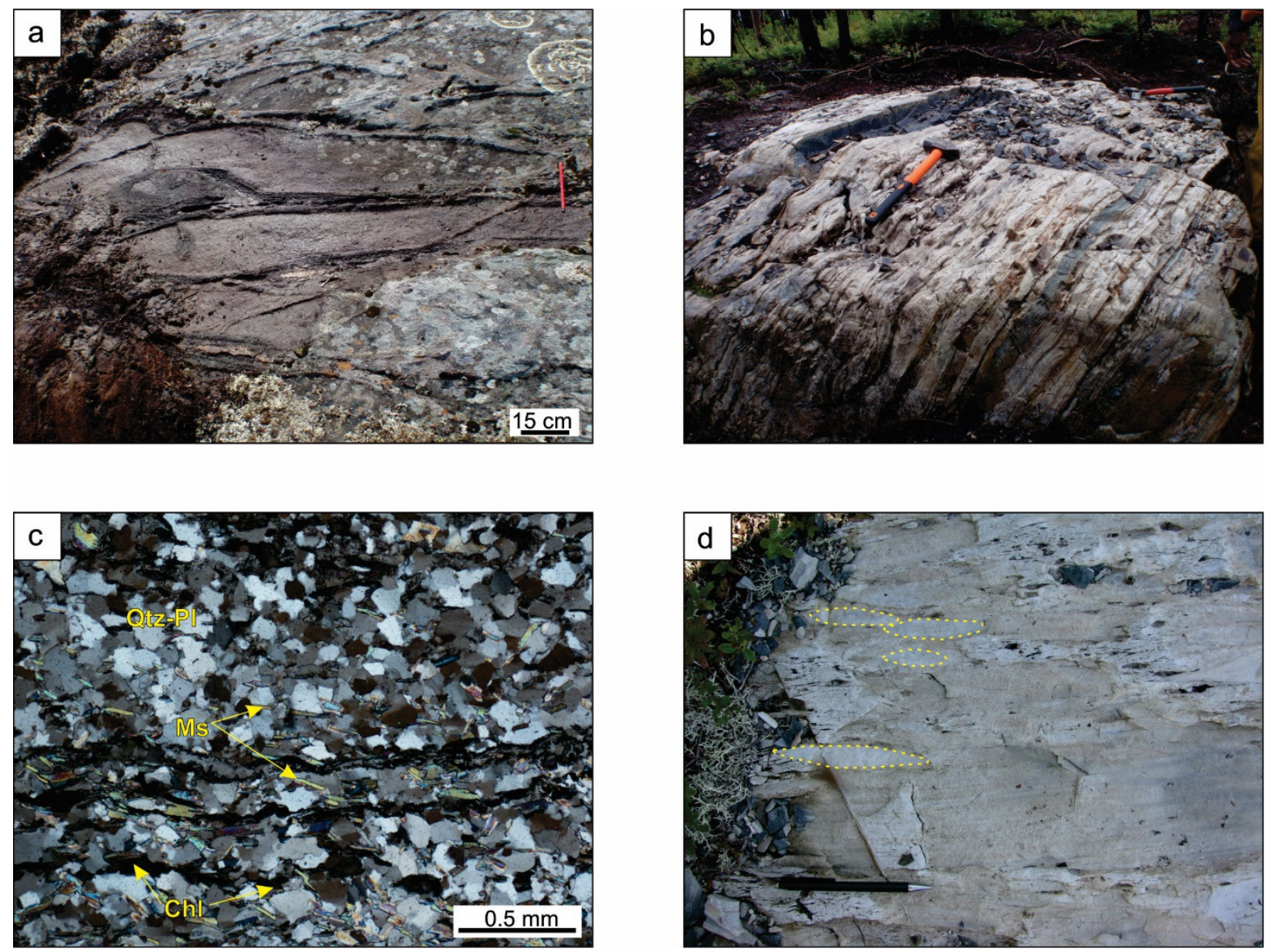

Fig. 4 Pillowed andesite lava and volcaniclastic rocks of the Colomb-Chaboullié greenstone belt. (a) Pillowed lava flows of Acch $2 a$ andesite, (b) and (c) outcrop and photomicrograph (cross-polarized light) of laminated volcaniclastic unit, and (d) lapilli tuff with some bombs (lapilli and bombs highlighted by dashed lines). Abbreviations: Chl = chlorite; $\mathrm{Ms}=$ muscovite; $\mathrm{Pl}=$ plagioclase; $\mathrm{Qtz}=$ quartz. Orange hammer is $40 \mathrm{~cm}$ long, black pencil is $15 \mathrm{~cm}$ long. 

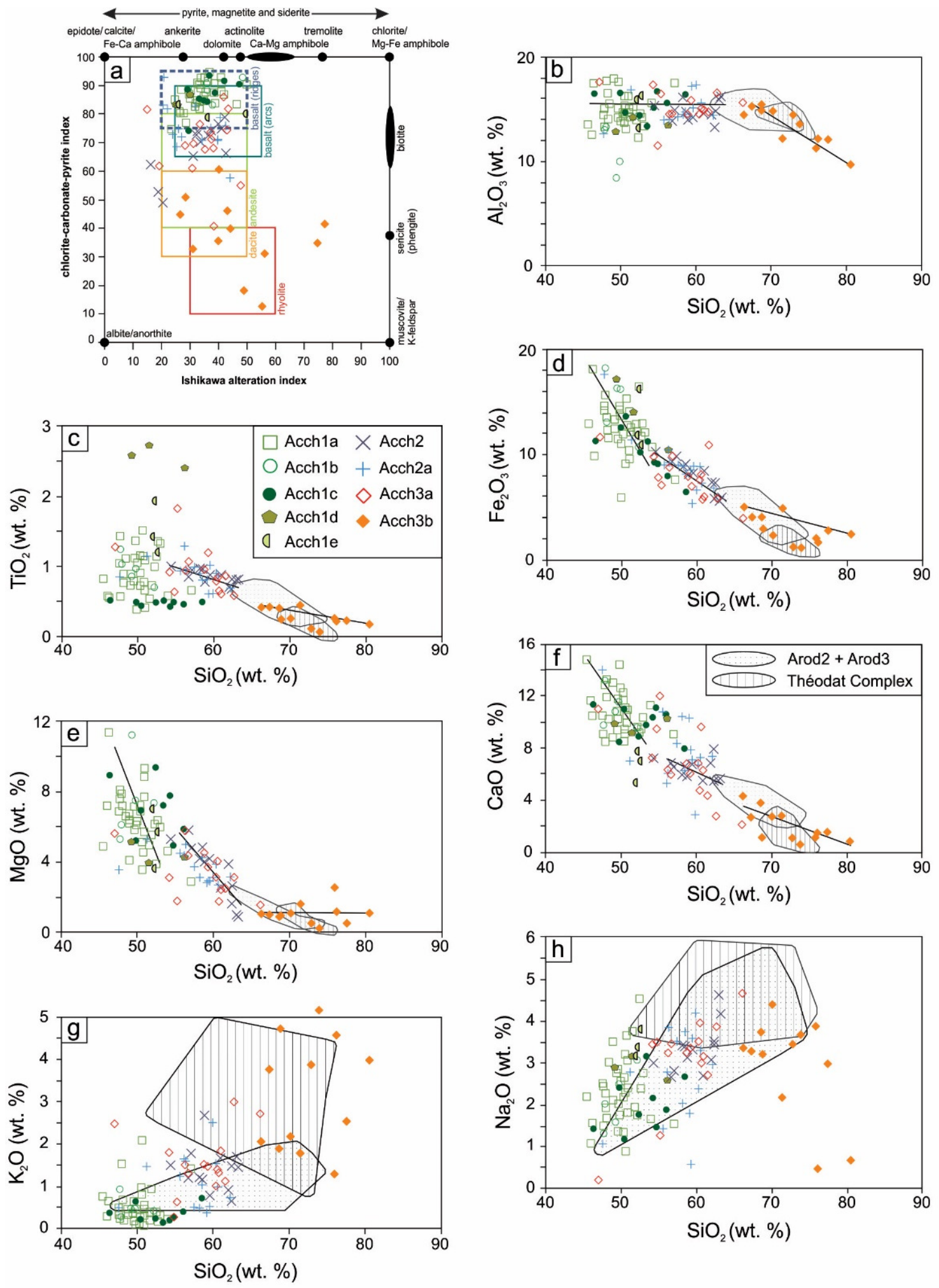

Fig. 5 Alteration box plot and Harker compositional diagrams for the Colomb-Chaboullié greenstone belt. (a) AI-CCPI alteration box plot (after Large et al., 2001). $\mathrm{AI}=100\left(\mathrm{~K}_{2} \mathrm{O}+\mathrm{MgO}\right) /\left(\mathrm{K}_{2} \mathrm{O}+\mathrm{MgO}+\mathrm{Na}_{2} \mathrm{O}+\mathrm{CaO}\right) ; \mathrm{CCPI}=100(\mathrm{MgO}$ $\left.+\mathrm{FeO}^{\mathrm{t}}\right) /\left(\mathrm{MgO}+\mathrm{FeO}^{\mathrm{t}}+\mathrm{Na}_{2} \mathrm{O}+\mathrm{K}_{2} \mathrm{O}\right)$. The box for unaltered ridge basalts on the alteration box plot is from Rogers et al. (2014) and the least altered boxes for arc basalts to rhyolites are derived from Gifkins et al. (2005). The poles for biotite and various amphiboles are from Caté et al. (2015). (b) - (h) $\mathrm{SiO}_{2}$ versus $\mathrm{Al}_{2} \mathrm{O}_{3}, \mathrm{TiO}_{2}, \mathrm{Fe}_{2} \mathrm{O}_{3}, \mathrm{MgO}, \mathrm{CaO}$, $\mathrm{K}_{2} \mathrm{O}$, and $\mathrm{Na}_{2} \mathrm{O}$. Trend lines are included on the Harker diagrams in order to provide visual aid between the mafic, intermediate and felsic trends. Abbreviations: Arod2 + Arod3: subunits of the Lac Rodayer pluton. 

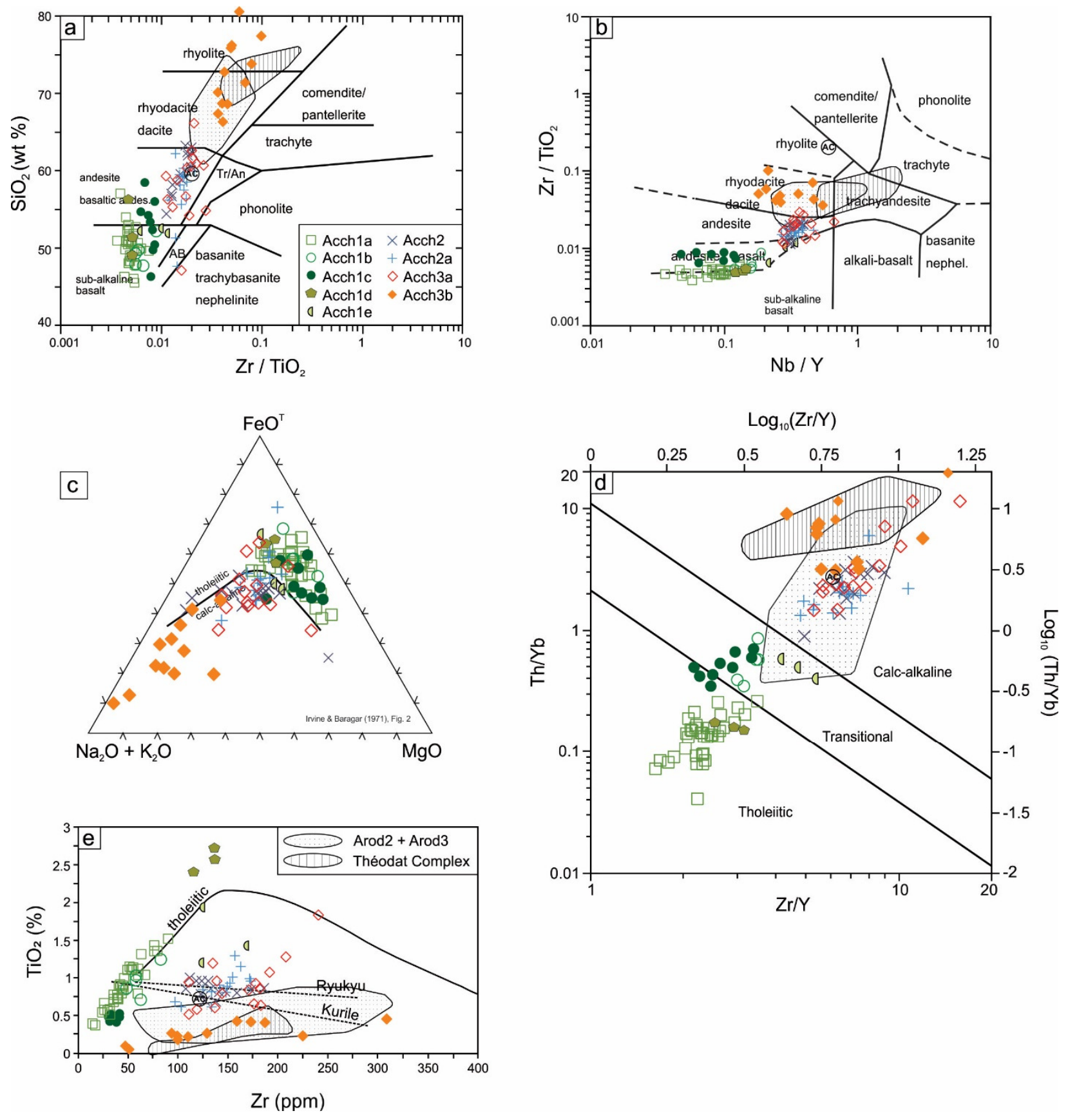

Fig. 6 Classification and magmatic affinity diagrams for the Colomb-Chaboullié greenstone belt. (a) and (b) Winchester and Floyd (1977) classification diagrams. (c) Alkali-total iron-magnesium (AFM) diagram. (d) Magmatic affinity diagram from Ross and Bédard (2009). (e) $\mathrm{TiO}_{2}$ vs. $\mathrm{Zr}$ plot. AC; average Archean crust value, after Rudnick and Fountain (1995). The tholeiitic trend line is taken from MacLean and Barrett (1993). The calc-alkaline trend lines are based on mafic to felsic volcanic rocks from the Kurile and Ryukyu arcs, compiled from the GEOROC database (http://georoc.mpch-mainz.gwdg.de/georoc/). Analyses for the Kurile arc were initially obtained by Tsvetkov et al. (1985), Aoki et al. (1999), Takagi et al. (1999) and Frolova et al. (2001). Analyses for the Ryukyu arc are from Miyoshi et al. (2005, 2008, 2009, 2010) and Almberg et al. (2008). All modern arc data was plotted on the AFM diagram, and any samples in the tholeiitic field were eliminated to get a calc-alkaline trend in (e). Abbreviations; Arod2 + Arod3: subunits of the Lac Rodayer pluton. 

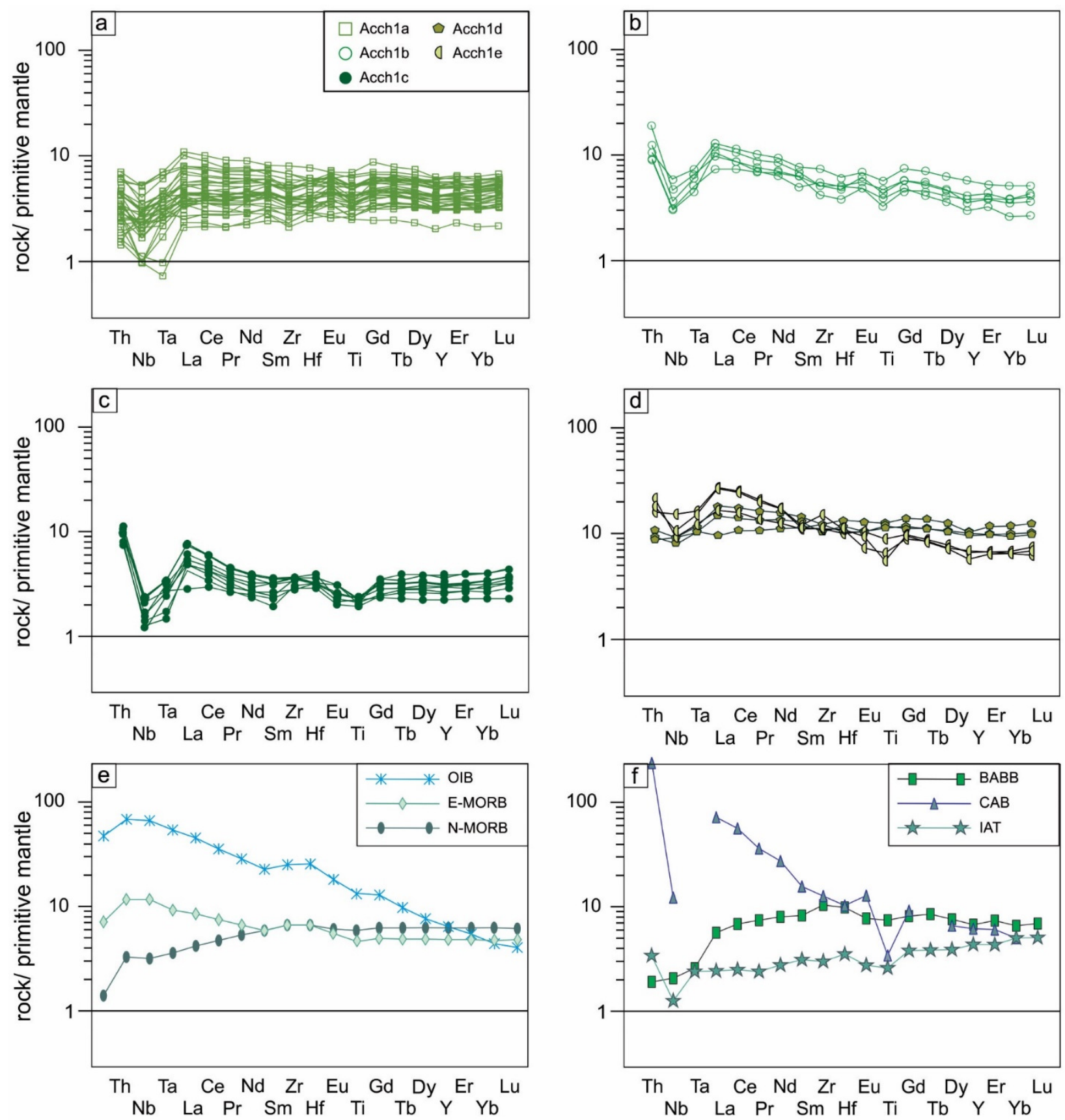

Fig. 7 Extended multi-element plots for the mafic lavas of the Colomb-Chaboullié greenstone belt. a) Acchla, b) Acchlb, c) Acchlc, d) Acchld and Acchle, e) modern non-arc basalts, and f) modern arc basalts. Primitive mantle normalization values, normal mid-ocean ridge basalts (N-MORB), enriched mid-ocean ridge basalts (E-MORB), and ocean island basalts (OIB) are from Sun and McDonough (1989). The values for calc-alkaline basalts (CAB) and island arc tholeiites (IAT) are from Stolz et al. (1990), and for back-arc basin basalts (BABB) are from Ewart et al. (1994). 

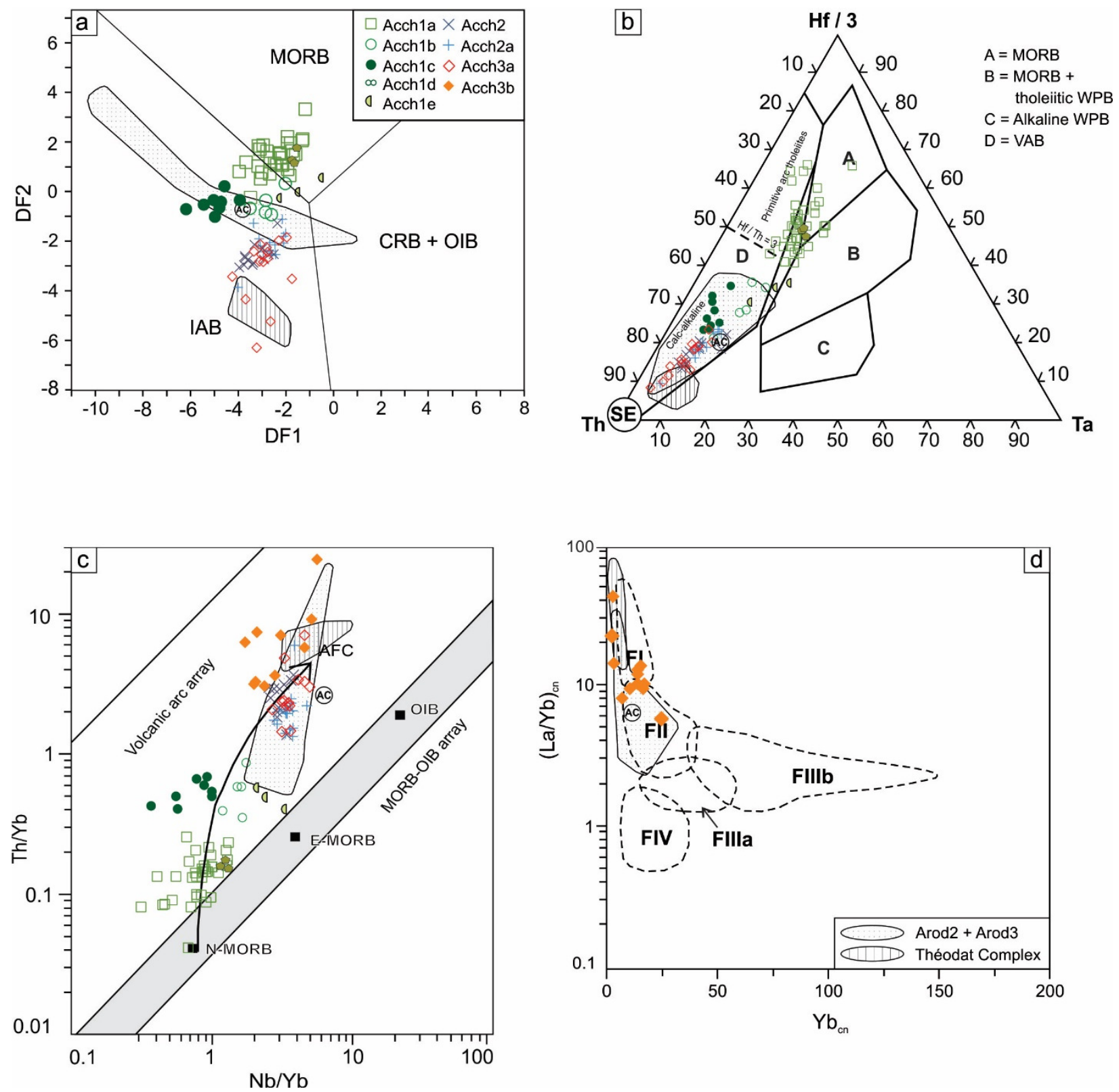

Fig. 8 Tectonic discrimination and rhyolite fertility diagrams. a) DF1-DF2 diagram of Agrawal et al. (2008). DF1=0.3518 $\log _{\mathrm{e}}(\mathrm{La} / \mathrm{Th})+0.6013 \log _{\mathrm{e}}(\mathrm{Sm} / \mathrm{Th})-1.3450 \log _{\mathrm{e}}(\mathrm{Yb} / \mathrm{Th})+2.1056 \log _{\mathrm{e}}(\mathrm{Nb} / \mathrm{Th})-5.4763 ; \mathrm{DF} 2=-0.3050 \log _{\mathrm{e}}(\mathrm{La} / \mathrm{Th})$ $-1.1801 \log _{\mathrm{e}}(\mathrm{Sm} / \mathrm{Th})+1.6189 \log _{\mathrm{e}}(\mathrm{Yb} / \mathrm{Th})+1.2260 \log _{\mathrm{e}}(\mathrm{Nb} / \mathrm{Th})-0.9944$. IAB: island arc basalts; MORB: midocean ridge basalts; CRB: continental rift basalts; OIB: ocean island basalts. b) Th-Hf-Ta ternary diagram from Wood (1980). The Archean crust (AC); after Rudnick and Fountain (1995) and subduction enrichment (SE) values are indicated. N-MORB: normal mid-ocean ridge basalts; E-MORB: enriched mid-ocean ridge basalts; WPB: withinplate basalts, VAB: volcanic arc basalts. c) $\mathrm{Th} / \mathrm{Yb}$ vs. $\mathrm{Nb} / \mathrm{Yb}$ diagram from Pearce (2008). AFC: assimilationfractional crystallisation. (d) $(\mathrm{La} / \mathrm{Yb})_{\mathrm{cn}}$ versus $\mathrm{Yb}_{\mathrm{cn}}$ after Hart et al. (2004). FI: alkali dacites and rhyodacites; FII: calc-alkaline rhyodacites and rhyolites; FII: tholeiitic rhyolites; FIV: depleted rhyolites and high-silica rhyolites. Abbreviations; Arod2 + Arod3: subunits of the Lac Rodayer pluton. 

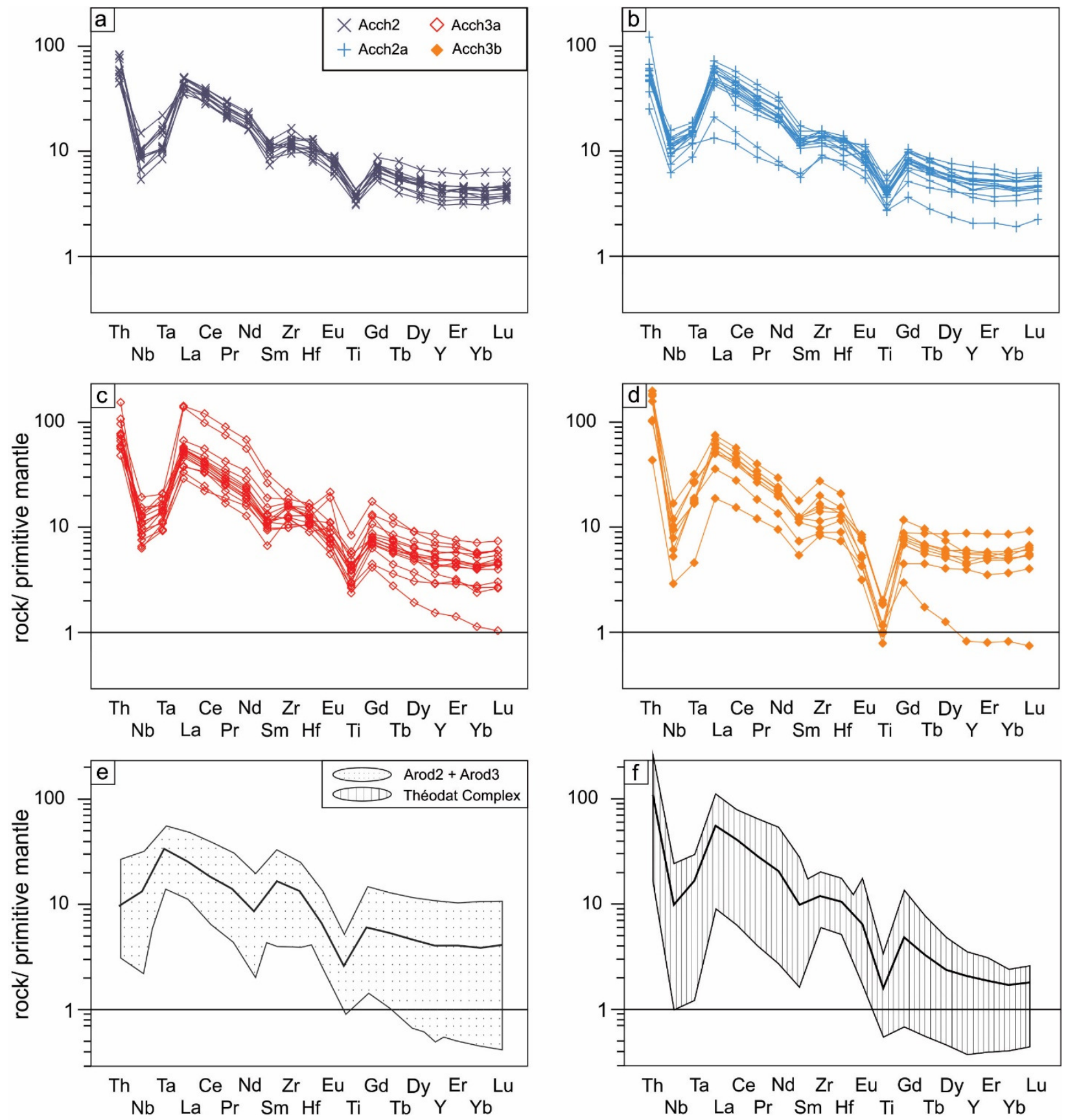

Fig. 9 Extended multi-element diagrams for the intermediate extrusive lavas, and intermediate to felsic volcaniclastic rocks of the Colomb-Chaboullié belt, as well as possible contaminants from the Opatica Subprovince. a) Acch2, b) Acch2a, c) Acch3a, d) Acch3b, e) Arod2 + Arod3, and f) Théodat Complex. Solid lines represent averages in (e)-(f). Primitive mantle normalisation values are from Sun and McDonough (1989). Abbreviations; Arod2 + Arod3: subunits of the Lac Rodayer pluton. 

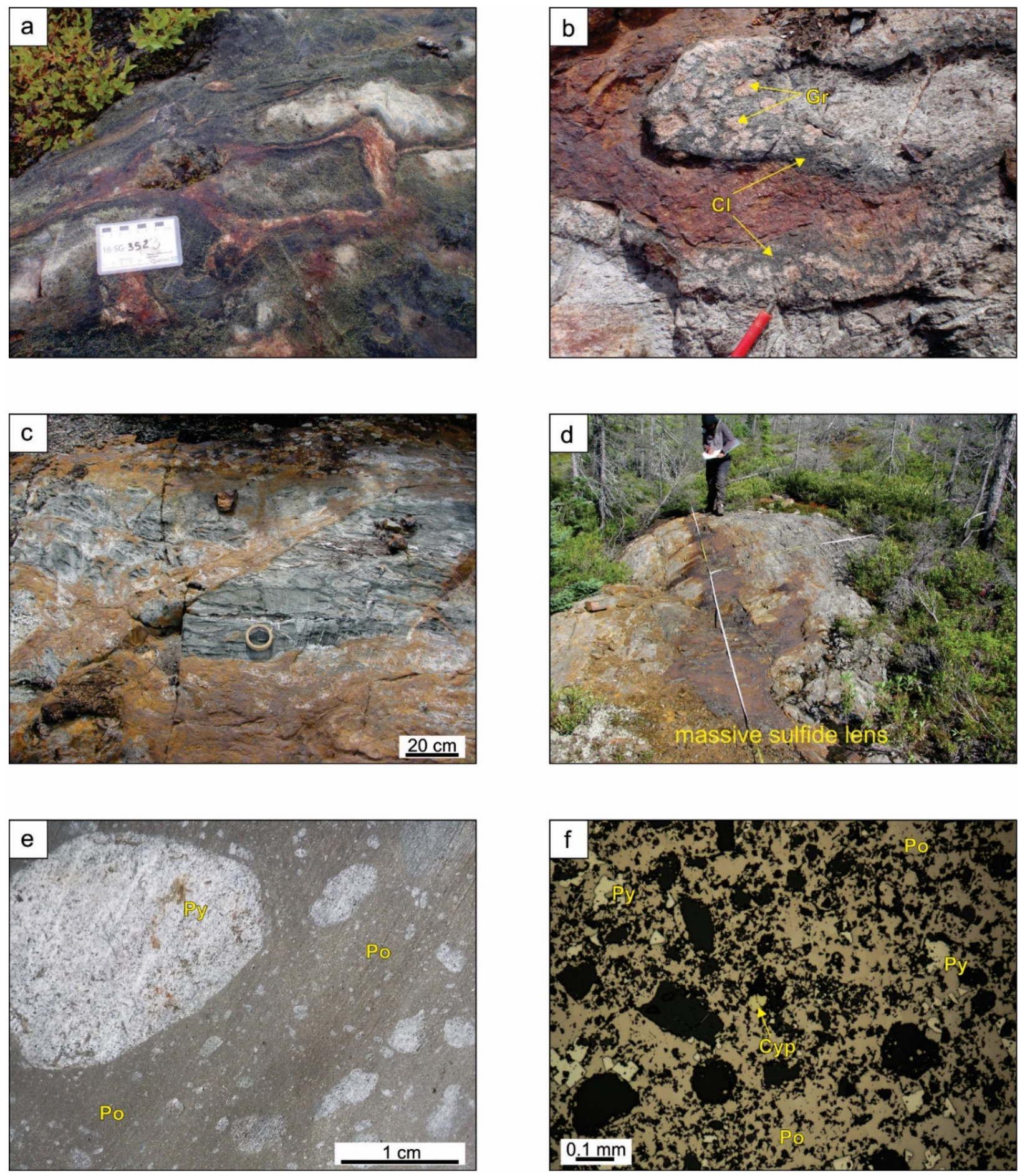

Fig. 10 Mineralisation of the Colomb-Chaboullié greenstone belt. a) Deformed pillowed basalt with disseminated sulphides in the inter-pillow material, b) synvolcanic alteration of chlorite and garnet in the pillow margins, c) sulphide veins in a massive basalt flow, d) the Lac Marcaut sulphide lens containing gold values, e) rounded siliceous fragments containing pyrite, embedded in a pyrrhotite-rich matrix, and f) reflected light image of a massive sulphide sample from the Lac Marcaut showing. Abbreviations: $\mathrm{Cl}=$ chlorite, $\mathrm{Cyp}=$ chalcopyrite, $\mathrm{Gr}=$ garnet, $\mathrm{Po}=$ pyrrhotite, $\mathrm{Py}=$ pyrite. 


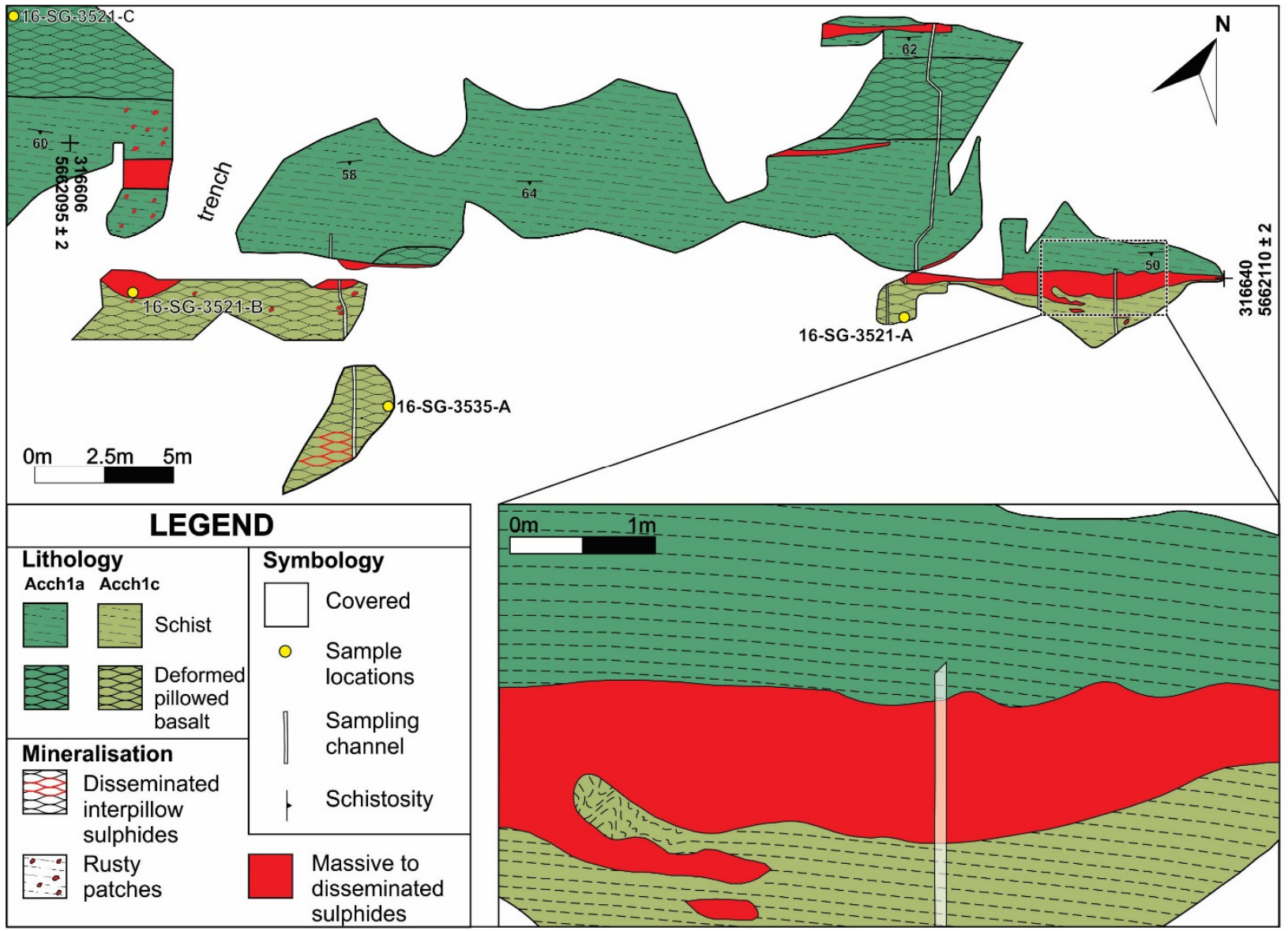

Fig. 11 Detailed map of the Lac Marcaut outcrop. 

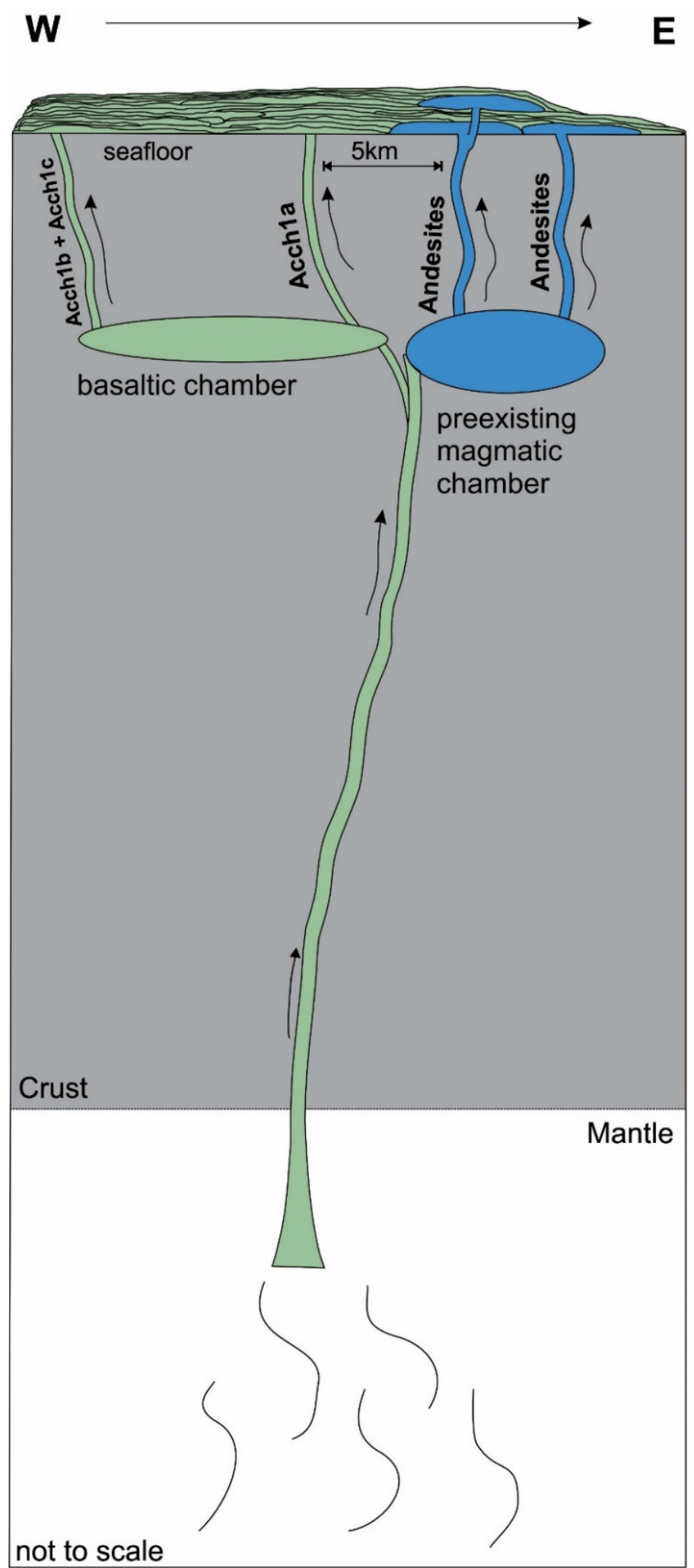

Fig. 12 Schematic diagram illustrating the emplacement of the mafic and intermediate lava flows of the Colomb-Chaboullié belt. Mixing in a pre-existing magma chamber may produce intermediate compositions. Inspired by Tawasewicz et al. (2012). 
Table 1 Average major oxide and trace element geochemical characteristics of the volcanic units of the Colomb-Chaboullié belt.

\begin{tabular}{|c|c|c|c|c|c|c|c|c|c|}
\hline & \multicolumn{5}{|c|}{$\operatorname{Acch}^{(1)}$} & \multicolumn{2}{|c|}{$\operatorname{Acch} 2^{(2)}$} & \multicolumn{2}{|c|}{$\operatorname{Acch} 3^{(3)}$} \\
\hline & Acchla & Acchlb & Acchlc & Acchld & Acchle & Acch2 & Acch $2 a$ & $\operatorname{Acch} 3 a$ & Acch $3 b$ \\
\hline \multicolumn{10}{|l|}{$w t . \%$} \\
\hline $\mathrm{SiO}_{2}$ & 50.05 & 49.38 & 52.89 & 52.31 & 52.23 & 58.62 & 57.48 & 58.35 & 69.11 \\
\hline $\mathrm{TiO}_{2}$ & 0.873 & 0.960 & 0.478 & 2.569 & 1.519 & 0.806 & 0.888 & 0.909 & 0.336 \\
\hline $\mathrm{Al}_{2} \mathrm{O}_{3}$ & 14.65 & 11.75 & 15.44 & 13.46 & 15.09 & 14.60 & 14.88 & 15.19 & 13.41 \\
\hline $\mathrm{Fe}_{2} \mathrm{O}_{3}{ }^{\mathrm{T}}$ & 12.83 & 15.00 & 10.27 & 13.95 & 13.13 & 8.57 & 9.13 & 7.93 & 4.36 \\
\hline $\mathrm{MgO}$ & 6.39 & 7.50 & 6.67 & 4.45 & 5.47 & 3.90 & 3.68 & 3.80 & 2.18 \\
\hline $\mathrm{MnO}$ & 0.307 & 0.307 & 0.261 & 0.251 & 0.177 & 0.153 & 0.185 & 0.171 & 0.094 \\
\hline $\mathrm{CaO}$ & 10.80 & 10.98 & 9.93 & 9.75 & 6.69 & 7.19 & 7.83 & 6.76 & 3.86 \\
\hline $\mathrm{K}_{2} \mathrm{O}$ & 0.47 & 0.47 & 0.32 & 0.21 & 0.64 & 1.19 & 1.15 & 1.52 & 2.33 \\
\hline $\mathrm{Na}_{2} \mathrm{O}$ & 2.24 & 2.09 & 2.01 & 2.88 & 3.45 & 3.20 & 2.67 & 3.11 & 2.55 \\
\hline LOI & 1.26 & 1.08 & 1.43 & 0.22 & 0.96 & 1.28 & 1.36 & 1.62 & 1.18 \\
\hline Total & 99.9 & 99.6 & 99.7 & 100.3 & 99.6 & 99.7 & 99.5 & 99.7 & 99.5 \\
\hline \multicolumn{10}{|l|}{ ppm } \\
\hline $\mathrm{Sc}$ & 39.3 & 30.0 & 46.6 & 40.2 & 24.7 & 20.1 & 16.9 & 15.9 & 11.6 \\
\hline $\mathrm{Cr}$ & 297 & 188 & 259 & 75 & 88 & 119 & 101 & 167 & 85 \\
\hline Co & 51 & 56 & 50 & 44 & 36 & 25 & 24 & 24 & 13 \\
\hline $\mathrm{Ni}$ & 132 & 125 & 108 & 44 & 58 & 60 & 56 & 74 & 38 \\
\hline $\mathrm{Rb}$ & 18 & 14 & 10 & 4 & 25 & 73 & 39 & 57 & 68 \\
\hline $\mathrm{Sr}$ & 131 & 137 & 81 & 141 & 192 & 328 & 352 & 387 & 226 \\
\hline Y & 18.8 & 18.8 & 14.0 & 45.3 & 29.2 & 19.3 & 22.6 & 22.1 & 20.0 \\
\hline $\mathrm{Zr}$ & 44 & 62 & 37 & 130 & 139 & 121 & 145 & 162 & 133 \\
\hline $\mathrm{Nb}$ & 1.7 & 3.0 & 1.1 & 6.3 & 8.4 & 5.8 & 7.8 & 7.9 & 5.2 \\
\hline Cs & 1.3 & 0.6 & 1.4 & 0.2 & 0.8 & 3.9 & 3.0 & 3.7 & 2.5 \\
\hline $\mathrm{La}$ & 3.14 & 7.11 & 3.33 & 9.72 & 16.13 & 25.41 & 32.44 & 41.61 & 28.81 \\
\hline $\mathrm{Ce}$ & 7.98 & 16.62 & 7.36 & 24.87 & 38.83 & 51.09 & 65.33 & 84.47 & 56.94 \\
\hline $\operatorname{Pr}$ & 1.19 & 2.25 & 0.92 & 3.71 & 5.02 & 5.86 & 7.48 & 9.71 & 6.16 \\
\hline $\mathrm{Nd}$ & 6.01 & 10.33 & 3.98 & 18.23 & 21.30 & 22.24 & 28.35 & 36.31 & 22.15 \\
\hline Sm & 2.01 & 2.87 & 1.23 & 5.66 & 5.10 & 4.10 & 5.29 & 6.27 & 4.24 \\
\hline $\mathrm{Eu}$ & 0.772 & 0.967 & 0.425 & 1.877 & 1.523 & 1.170 & 1.446 & 1.654 & 0.903 \\
\hline Gd & 2.77 & 3.42 & 1.73 & 7.26 & 5.61 & 3.80 & 4.71 & 5.19 & 3.79 \\
\hline $\mathrm{Tb}$ & 0.50 & 0.58 & 0.33 & 1.29 & 0.92 & 0.59 & 0.71 & 0.74 & 0.59 \\
\hline Dy & 3.29 & 3.49 & 2.30 & 8.25 & 5.48 & 3.52 & 4.07 & 4.11 & 3.61 \\
\hline Ho & 0.69 & 0.69 & 0.50 & 1.70 & 1.09 & 0.70 & 0.80 & 0.79 & 0.72 \\
\hline Er & 2.04 & 2.02 & 1.53 & 4.99 & 3.18 & 2.04 & 2.34 & 2.25 & 2.15 \\
\hline $\mathrm{Yb}$ & 2.06 & 1.91 & 1.62 & 5.10 & 3.25 & 2.08 & 2.28 & 2.09 & 2.20 \\
\hline $\mathrm{Lu}$ & 0.330 & 0.299 & 0.264 & 0.799 & 0.508 & 0.329 & 0.360 & 0.332 & 0.363 \\
\hline $\mathrm{Hf}$ & 1.3 & 1.6 & 1.0 & 3.6 & 3.3 & 3.0 & 3.5 & 3.8 & 3.4 \\
\hline Ta & 0.14 & 0.25 & 0.10 & 0.44 & 0.60 & 0.49 & 0.60 & 0.59 & 0.66 \\
\hline Th & 0.28 & 1.03 & 0.81 & 0.82 & 1.58 & 4.37 & 4.55 & 6.40 & 9.36 \\
\hline
\end{tabular}

1. Basaltic lavas

2. Intermediate lavas

3. Intermediate to felsic volcaniclastic rocks 